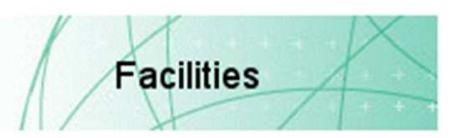

\title{
CAN SELF-EVALUATION MEASURE THE EFFECT OF IEQ ON PRODUCTIVITY? A review of literature
}

\begin{tabular}{|r|l|}
\hline Journal: & Facilities \\
\hline Manuscript ID & f-08-2016-0087.R1 \\
\hline Manuscript Type: & Original Article \\
\hline Keywords: & $\begin{array}{l}\text { Building evaluation, Ergonomics, Perception, Performance measurement, } \\
\text { Post occupancy evaluation, Productivity }\end{array}$ \\
\hline \multicolumn{2}{|l}{} \\
\hline
\end{tabular}


Abstract

The purpose of this review is to investigate the use of self-evaluation as a method for measuring the productivity of office workers. The objective is to highlight issues associated with self-evaluation and barriers to its insufficiency in capturing occupant productivity in its totality. The literature includes referred journal and conference papers. A review of available literature was carried out on the subject of perceptions studies and self-evaluation as well as occupant performance in the office environment. Studies that employed the use of self-evaluation (questionnaires or interview) as the sole method of measuring the effect of IEQ on productivity/performance were reviewed. The discussions carried out in this paper show that self-evaluation is compromised by various issues that significantly affect the validity of their results. As such, it is insufficient as a sole method for measuring occupant productivity (cognitive performance) and the influence of IEQ on it. This review is carried out on available literature on past studies. Empirical evidence is required to test the reliability of self -evaluation in measuring productivity and the effect of factors such as IEQ on it. We demonstrated that self-evaluation methods of measuring productivity were affected by various research related issues. They are insufficient and do not accurately measure productivity. As such, it cannot be claimed that a comfortable IEQ results in a productive occupant based on results from self-evaluation studies. If such claims are to be made, more accurate methods of assessment are required. This paper provides a novel view on the reliability of self -evaluation results on the effect of IEQ on productivity.

Keywords: Occupant productivity, Indoor Environment Quality, Office environments.

\section{Introduction}

Building performance concerning indoor environment quality (IEQ) has gained increasing attention in recent years. The fact that people spend around $90 \%$ of their time indoors (Klepeis et al., 2001) has made the implications of the indoor environment imperative to designers. There is evidence towards a consensus view that the IEQ conditions that result in comfort do, in fact, increase the productivity of occupants (Lan and Lain, 2009; Hameed and Amjad, 2009; Liu et al., 2010; Kekalainen et al., 2010). However, recent studies have findings that indicate that there is no causal link between occupant productivity and IEQ (Zhang et al., 2011; Mak and Lui, 2012; McCunn and Gifford, 2012; Healey and Webster-Mannison, 2012) in office environments. But this assumes that the methods of measuring productivity have validity. Perception study, expressly questionnaires that ask occupants to evaluate their perceived productivity (Leaman, 2012) is a conventional method that has been used to measure the cognitive performance of workers. A literature review carried out by Onyeizu (2015) wherein the author review past works on the relationship between IEQ and occupant productivity in Green office spaces showed that majority of studies in this subject area had employed the use of self-evaluated productivity (questionnaires or interviews) as their method of investigation. But then, how reliable is a self-evaluated productivity in measuring the performance of workers in the office environment?

Measuring how productive an office worker is on a day to day activity for an average working period remains a subject of debate (CABE, 2004; Lee and Brand, 2010). Senshama et al., (1998) noted that there are gaps in existing knowledge about non-industrial productivity measurement and claim that current literature presents contradictory evidence about links between human responses and occupant productivity. Haynes (2008) identified the measure of productivity and the effects of the office environment on the productivity of occupants as two main areas that require further research. In the absence of a test that can directly relate increased monetary gain to the achievement of environmental criteria, research into productivity needs to focus on a) whether the environmental standards are appropriate and $b$ ) whether the tests for productivity are relevant and robust. 
The purpose of this paper is to assess the sufficiency of self-evaluated productivity in measuring the effect of IEQ on productivity in offices through a review of literature on the potential bias and their effects on the validity of results. Previous literature reviews on IEQ and occupant productivity (Abdou et al., 2006; Frontczak and Wargocki, 2011; Hauge et al., 2011) have concentrated on finding absolute effects of physical and non-physical components of IEQ on occupant comfort and satisfaction that can be related to productivity. Such reviews have been equivocal in their support for the claim that IEQ is responsible for productivity, but none of them critically examined the measurement methods involved. There is the need to review self-evaluation as a method for productivity assessment and establish its strengths and weaknesses in this area of research. It is important to point out that this article does not address the effect of the specification of internal materials, cleanliness or maintenance (Kumar and Fisk, 2002) on comfort, health, and productivity.

\section{Methodology}

The purpose of this review is to investigate the use of self-evaluation as a method for measuring the productivity of office workers. The objective is to highlight issues associated with self-evaluation and barriers to its insufficiency in capturing occupant productivity in its totality. The literature includes referred journal and conference papers. A review of available literature was carried out on the subject of perceptions studies and self-evaluation as well as occupant performance in the office environment. A search of keywords: performance, indoor environment quality, productivity, questionnaire, and interview was carried out on studies published after the year 2000 to reflect the current state of the art in research and its relevance in this field. Studies that employed the use of self-evaluation (questionnaires or interview) as the sole method of measuring the effect of IEQ on productivity/performance were selected. It was also important that these studies are from reputable journals and conferences and are of good quality. Table 1 shows the selected studies with their respective journal's impact factor and citations. The search was done through Google Scholar and Science Direct engines. The bibliographies of collected articles were examined to identify relevant articles that might have been missed during the search.

Twenty-six (26) findings were found to be of importance to this review. While most of the studies found a causal link between IEQ and productivity, others used productivity as the criterion to determine thresholds for comfort or satisfaction.

3. Results

Table 1 summarises the papers and their findings. A discussion on the use of self-evaluation in measuring the relationship between IEQ and productivity is presented. Productivity is discussed regarding the factors that can affect it in the office environment. Potential bias that can influence the validity of self-evaluation is also presented to illustrate the degree of effect these bias can have on results as well as their significance in an area of research that has much influence on office design and productivity.

The intention of this paper is not to discredit the science behind perception study or make light the contributions self-evaluation has made to research especially in areas such as post-occupancy evaluation of buildings. Rather, it is to highlight the insufficiency of self-evaluation as a sole method for measuring occupant productivity (cognitive performance) and the influence of IEQ on it.

\subsection{Bias in human research}

Human research is potentially affected by bias. This effect results from the fact that people's desires, preferences, and perceptions are subject to change. They are also affected by numerous factors including culture, trends, and biological makeup. Some sources of bias have been identified over the 
years of research to have a substantial influence on occupant's perceptions and judgements of their environment. Examples are the Hawthorne effect (McCarney et al., 2007), placebo effect (Hrobjartsson \& Norup, 2003), experimenter expectancy effect (Rosenthal, 2004), social desirability bias (Callegaro, 2008) and novelty effect (Yang et al., 2009). These may distort the outcome of research and result in diverging outcomes.

Hawthorne effect: The Hawthorne effect occurs when a study outcome is affected by the mere knowledge of being under observation. The Hawthorne effect was first noted by two engineers in 1924 in an experiment that tested the effects of lighting and salary on worker productivity (Levitt and List, 2007). Over the years, this effect has had an enormous impact on research and is a prominent source of bias in field studies (Levitt and List, 2011; Kampschroer and Heerwagen, 2005). It has also been influential in suggesting the effect of factors other than IEQ on productivity (Haynes, 2007c).

However, this effect may not be easy to eliminate since most of the time participants of field studies are aware of the study conducted on them. The mere fact of participation in the study, repetition of experiment (in studies monitoring effects of a stimulus on the participation) and the 'experimenter demand effects' (Levitt and List, 2007) are reminders to the participants of the intention of the study (Levitt and List, 2011) especially in questionnaires and interviews as instruments for measurement.

Placebo effect: The Placebo effect is related to the perceptions and expectations of the study participant. If the participant expects an aspect of the physical environment to affect his/her productivity, it is likely that the participant will respond to this expectation. As it is with the medical placebo treatment, an effect of IEQ can be perceived even though it is non-existent. This effect can be found in research where participants are examined on variables they have a preconceived perception or expectation about; even when it is not the intention of the researcher to initiate such effects.

Experimenter expectancy effect: In the case of the experimenter expectancy effect, the researcher's cognitive bias on the study influences its outcome. Though this effect might be an unconscious act, it is quite evident in a majority of questionnaire and interview-based studies. The type and nature of questions asked to a participant can be leading and suggest the direction of result expected. For example, if a participant is asked the question "Please estimate how you think your productivity at work is decreased or increased by the environmental conditions in the building", it is possible that the respondents will state an increase as long as the environmental conditions are within an acceptable range and do not negatively impact on their comfort. While this question might not be intended to mislead, it is unlikely that respondents will rate $0 \%$ if the environmental conditions have not increased his productivity but is comfortable or acceptable. This question can only be answered if the respondent has been in a previous building with worse indoor environment quality and can compare the two conditions.

On another note, productivity is a sensitive issue especially for an employee who is trying to prove him or herself worthy of his job. As such, the likelihood that an employee will state that his/her productivity hasn't increased is little. Such an instance could explain why even though occupants report high rates of dislike for the environmental conditions in their building; they still rate their productivity to have increased (Baird, 2010). Could it be that it is the undesirability of the environmental conditions that increased the productivity of these occupants?

Social desirability: Another source of bias is that of social desirability which is mostly found in questionnaire surveys. Most questionnaires are distributed to occupants in a building that either has an open plan space or offices with two-four occupants (Kaarlela-Tuomaala et al., 2009, Newsham et al., 
2009) where there is possible communication amongst the occupants. It is impossible to know for sure that answers given to questions are valid and have not been affected by what other occupants think or the general perception amongst co-workers even if the respondent has not experienced such an effect personally. The likelihood of this effect increases if questionnaires are filled out at lunch time or are not collected until the next day.

Novelty effect: The novelty effect is most evident in intervention studies where the effect of change is investigated. An example is the effect of office renovation or movement from an old office building to a new one or the introduction of new technologies (Kaarlela-Tuomaala et al., 2009, Thomas 2010, Kakalainen et al., 2010). There is the tendency of an increase in productivity to be observed as a result of the introduction of a new product or technology, not because of the actual effect but due to an interest in the introduced product. People tend to patronise a new product not because the new product is better than the old but as a result of curiosity. For instance, the introduction of new furniture, a new lighting system and even a new HVAC in an office space can have an influence on the productivity of occupants. In this case, the increase in productivity whether it is reported or observed might be a function of the novelty of the work environment or equipment and not a function of an actual improvement due to the efficiency of the environment. People might want to go to work just because they have a new "cool" environment to work in. The downside of the novelty effect is that it is likely to be temporary. Its effect will wear off when the occupants become accustomed to the environment.

While all of these sources of bias might not be evident in all studies, some of them have greatly influenced research outcomes which might be a reason for conflicting or erroneous results on the subject of IEQ and occupant productivity in office buildings. These factors are constantly in play and can pose challenges to the validity of findings.

\subsection{Productivity Proxy indicators}

Self-assessed (perceived) and actual productivity: Research is yet to prove the best way to measure the performance of workers especially for outputs that cannot be easily represented quantitatively. Leaman and Bordass (2007) understood this problem when they aptly noted that "in buildings, people are the best measuring instruments: they are just harder to calibrate." Most studies depend on self-evaluation as the way to capture information. In fact, a majority of the studies that have found an effect of IEQ on productivity have based their findings on questionnaires and interview. While interviews are more rigorous and demand a direct communication between the interviewer and the person interviewed, questionnaires are typically less in-depth and cover a larger population within a short time frame. Interviews can distort user-response since they raise the anticipation level of the respondents who can be prone to responding with answers that they anticipate will 'please' the interviewer (similar to the Hawthorne effect (McCarney et al., 2007). Various questionnaires are applied to building evaluation with the aim of obtaining feedback from occupants concerning the performance of their buildings. They include the CBE occupant questionnaire (Tanabe et al., 2013; Prakash, 2005) the BUS questionnaire (Baird et al., 2012; Lenior et al., 2012; Paevere and Brown, 2008; Thomas, 2010) and others designed specifically for the study purpose (Hepner and Boser, 2006; Roulet et al., 2006; Kaarlela-Tuomaala et al., 2009; Newsham et al., 2009). These questionnaires are designed to obtain the perception of occupants in the best way possible. The common trait is that the respondent (usually the occupant) is expected to make a judgment based on his/her experience with the IEQ of the study building and thus rate if his/her productivity has increased or decreased. In other words, if they felt that by increasing the temperature or lighting in the room that their productivity increased or decreased, they were expected to say so through the questionnaire or during the interview. 
The problem with this is that this only measures perceived productivity which is limited by the various sources of bias discussed earlier in this paper. Another issue with self-evaluation lies with understanding what the word "productivity" means to occupants and how they measure a change in productivity (Onyeizu, 2014). Self-evaluation cannot be a dependable substitute for an actual assessment of productivity especially when cost implications are considered. As Vischer (2008) suggested, a clearer distinction needs to be made between measuring user perceptions and judgments and measuring actual behavioural effects that are attributable to physical features.

\section{The error of singular questions}

A problem with the use of questionnaires is what that can be termed 'singular question'. This term is employed in this paper to describe a question that seems to represent several aspects of a topic. A singular question does not identify the various dimensions of the subject investigated but assumes that these aspects are represented in the question. For instance, if the singular question uses the word 'productivity', there is no provision to know what the respondents understand productivity to be and how they will measure it. Research has shown that there are many definitions of productivity. Some are highlighted in the table below. As such, determining which one the researcher is referring to or which one the respondent is answering to can create bias in results. Also, the response to singular questions is usually closed-ended which requires the respondent to select a reply from a list provided. Singular questions have the possibility of robbing the respondent of many options since one can only answer the question asked.

\subsection{Measuring productivity in the office environment}

Occupant productivity has been described as a complex phenomenon influenced by many factors (Lee, 2000; Buttonwood, 2013). A review of studies on the effects of environment on productivity concluded that confusion about what productivity means has made it difficult to identify how environmental conditions affect worker performance (CABE, 2004). Oseland (1999) also acknowledged the complexity of measuring inputs and outputs, especially in today's modern office. This problem is aggravated in the case of employees whose activities are human related. Most products of business organisations such as customer satisfaction and knowledge are not quantifiable and cannot be represented in numbers/values.

However, there have been attempts to quantify productivity in the office (Pulakos, 2007; Woods, 2002). For example, Neely (1998) suggested a method of quantifying past actions that determine current performance using efficiency and effectiveness as fundamental dimensions of performance. The author described efficiency as a measure of how economically the organisation's resources are utilised when providing a given level of customer satisfaction, and effectiveness as the extent to which customer requirements are met. Oseland (1999) is of the opinion that productivity is generally expressed in terms of efficiency. As such, it can be increased by either increasing output for the same input, or achieving the same output with reduced input (Haynes, 2007c). In other words, productivity can be obtained by producing the same output with fewer workers or producing more output with the same number of staff.

An interesting theory which can be viewed as a means of quantifying productivity in a work environment is that suggested by The US General Service Administration (GSA) (WBDG, 2012). It concluded that since people are the most valuable resource and greatest on-going expense of any organisation, the long-term cost benefits of a properly designed, user-friendly work environment should be factored into any initial cost considerations. WBDG (2012) suggested that one way to do such "factoring" would be to consider the total life-cycle costs of the building or property each year. It explains that an additional $\$ 2$ per square foot per year for bricks and mortar costs (e.g. for providing greater flexibility) would pay for itself if it generated a modest $1 \%$ increase in salary "productivity." As 
such, design strategies that increase user satisfaction and improve individual and group effectiveness should, therefore, be considered not as cost 'extras,' but as productivity investments that enhance an organisation's overall success.

Zhao et al. (2009)'s productivity model suggests that productivity varies with time from a developing stage to a mature stage to a decline stage. This notion brings to light another fact about productivity - in particular, change in productivity ( increase or decrease) - that it is not constant. Irrespective of the comfort level that is provided and how satisfied an occupant might be with an office environment, any increase in productivity is bound not to be maintained but to decline within a particular work time.

To illustrate this theory, let's assume that the productivity of occupants in a workplace is increased (notwithstanding the individual difference between occupants i.e. all things being equal). This increase could be as a result of an intervention on the work environment that causes satisfaction, comfort or even excitement with the new working conditions (e.g. novelty effect). At the end of this time of environmental awareness and familiarisation with the environment, the excitement stops ("Mature stage') even though satisfaction and/or comfort might not have reduced. At this stage, productivity remains the same (neither increasing nor decreasing). A time comes when the environment has become too familiar and standard that there is no more excitement. Then, productivity begins to drop and decline to tend towards the initial level. In this case, the IEQ has not changed but has been kept constant as at the time of introduction. This theory could explain factors such as complacency as causes of change in productivity. A likely source is 'emotional labour' -a situation where workers are expected to manage their feelings by organisationally defined rules and guidelines (Wharton, 2009). For instance, in white collar jobs that often involve selling one's personality along with one's labour ability, these workers are likely to get tired rapidly after some time which might cause a decline in productivity. This situation is not a function of the IEQ in the office environment.

Occupant productivity is indeed a complex phenomenon to measure. However, the various definitions of productivity given by researchers above indicate that the closest attempt to capture and thus measure productivity in its totality will require both objective and subjective performance measures that consider the intricacies of inputs and outputs in today's modern office. Self-evaluation does not provide an adequate platform for this.

\subsection{Diversity in Preference}

A workspace cannot be designed to be a one-time, final and permanent ergonomic support for all office tasks but rather needs to be adaptable and 'negotiable' to be supportive to users (Vischer, 2008). This is because people differ and respond differently to the same conditions (Frontczak and Wargocki, 2011). Studies that try to measure occupants' perception of their productivity under varying IEQ conditions with the aim of finding absolute correlations are often prone to the limitation that even though the physical requirements specified by research are met, not all building occupants are satisfied and motivated to perform specified tasks by the same physical conditions.

Many firms and organisations have workers from different backgrounds and cultures with different past experiences; and expectations. This diversity determines how various factors can affect productivity. It is possible that an occupant's response to any given environmental condition might be influenced by his/her perception of what an ideal environment should be from his/her experiences; which might not be the same as his/her colleagues. For instance, an occupant who has spent most of his/her lifetime in a warmer climate with less artificial lighting and continuous background noise might prefer an indoor environment closer to this situation. Also, an occupant whose experience has resulted in the preference 
for an individual space with minimal communication/ interference with colleagues might find an open plan workspace undesirable or detrimental to his productivity.

\subsection{Comfort/Satisfaction and productivity}

The relationship between comfort/satisfaction and productivity (Huizenga et al., 2006; Brager and Baker, 2009; Leaman and Bordass, 2001) has been an anchor in measuring the effect of IEQ on occupant productivity. Vischer (2008) noted that the link between satisfaction and productivity is the notion of comfort, specifically functional comfort which is an environmental support for users' performance of work-related tasks and activities. However, it is questionable whether comfort automatically results in productivity. It is possible that factors which amount to a comfortable environment might not be the best for a productive environment. For instance, Pepler and Warner (1968) found that young people worked best (and were thus more productive) for short periods when they were uncomfortably cold. The aim to escape the discomfort of the cold environment was in this case, a positive factor to stimulate greater productivity. Since this effect was found amongst young people (which makes up $90 \%$ of most organisations and are regarded as the healthy age group), one could draw on this and suggest that a bit of discomfort may have a positive effect on productivity.

On the other hand, determining what could scientifically indicate a comfortable environment is also the subject of debate. While some authors stipulate a certain range of IEQ as criteria for comfort, others suggest that there are no context-free indicators for indoor climates. Roaf (2005) pointed out that the conditions which people will find comfortable are influenced by the climatic, cultural, social and economic circumstances in which they find themselves. She added that even if it is possible to suggest an appropriate indoor temperature for various types of building purposes, it depends on the social and climatic context. Monfared and Sharples (2011) observed that the expectations of occupants in buildings are inevitably based on their previous experience of conventional workplaces and lack of control over environmental conditions.

4. Can the effects of IEQ on occupant productivity be measured?

The ability to measure how productive an occupant is and how this productivity can be influenced by external factors remains integral to the success of an organisation. However, accurate measurement is essential that recognises occupant productivity in totality. This becomes necessary where results of studies on IEQ and productivity are used as commercial incentives (Onyeizu, 2014). To accurately measure the effect of factors (in this case, IEQ) on productivity, the issues discussed in this paper need to be addressed.

It is also necessary to consider the magnitude at which each factor affects productivity. For instance, it is possible that a simple treat could have more effect on productivity than an increase in lighting or temperature. It is also possible that the life experiences of an occupant can have more influence on their perceived productivity than external views and daylighting.

Haynes (2007b) developed a theoretical framework for office productivity noting that the nature of office work has changed over the last century from that of a passive and static activity to that of a dynamic and flexible activity. His productivity framework proposed a balance in the relationship between the physical environment and the behavioural environment to achieve productivity. This notion is not novel to research as past studies on indoor environment have noted the effects of factors other than components of the physical environment (IEQ) on an occupant's productivity in the workplace (Roethlisberger and Dickson, 1939; Chau et al., 2006; Brauer and Mikkelsen, 2010; Leblebici, 2012; Meijer et al., 2009; Moshagen et al., 2009; Smith and Bayehi, 2003). A recent carried out on the relative importance of factors affecting productivity (Onyeizu and Byrd, 2014) showed that social and 
organisational were regarded more important to productivity than IEQ factors by the workers in office buildings.

\section{Conclusion}

Many studies on occupant productivity have accorded the change in productivity to variations in indoor environment quality (IEQ). In particular, worker performance in office spaces has been purported to be influenced or dependent on the precise levels of indoor environment conditions. The majority of these studies have employed self-evaluation as the methodology for measuring productivity. In this paper, we revisited the theory behind perception study and discuss the various potential issues that can affect the quality of results. The intention of this review is not to discredit perception study or make light the contributions self-evaluation has done to post occupancy evaluation of buildings. Rather, it is to highlight the insufficiency of self-evaluation in measuring occupant productivity (cognitive performance) and the influence of IEQ on it. The discussions carried out in this paper show that selfevaluation is compromised by various issues that significantly affect the validity of their results. We demonstrated that self-evaluation methods of measuring productivity were affected by various research related issues. They are insufficient and do not accurately measure productivity. As such, it cannot be claimed that a comfortable IEQ results in a productive occupant based on results from self-evaluation studies. If such claims are to be made, more accurate methods of assessment are required. This review is carried out on available literature on past studies. Empirical evidence is required to test the reliability of self -evaluation in measuring productivity and the effect of factors such as IEQ on it.

\section{References}

Klepeis, N., Nelson, W., Ott, W., Robinson, J., Tsnag A., Switzer, P., Behar, J., Hern, S. \& Engelmann, W., (2001). The National Human Activity Pattern Survey (NHAPS): A resource for assessing exposure to environmental pollutants, Journal of Exposure Analysis and Environmental Epidemiology, 11, $231-252$

Lan, L., \& Lian, Z. (2009). Use of neurobehavioral tests to evaluate the effects of indoor environment quality on productivity. Building and Environment, 44(11), 2208-2217. doi:10.1016/j.buildenv.2009.02.001.

Hameed, A. \& Amjad, S. (2009). Impact of Office Design on Employees' Productivity: A Case study of Banking Organizations of Abbottabad, Pakistan. Journal of Public Affairs, Administration and Management, 3(1), 1-13.

Liu, K., Chiang, C. \& Lin, Y. (2010). Influences of visual fatigue on the productivity of subjects using visual display terminals in a light-emitting diode lighting environment. Architectural Science Review, 53(4), 384-395.

Zhang, H., Arens, E., \& Pasut, W. (2011). Air temperature thresholds for indoor comfort and perceived air quality. Building Research \& Information, 39(2), 134-144. doi:10.1080/09613218.2011.552703.

Mak, C. \& Lui, Y. (2012). The effect of sound on office productivity. Building Services Engineering Research and Technology, 33(3), 339-345. doi:10.1177/0143624411412253.

McCunn, L. \& Gifford, R. (2012). Do Green offices affect employee engagement and environmental attitudes? Architectural Science Review, 55(2), 128-134. doi:10.1080/00038628.2012.667939.

Healey, K. \& Webster-Mannison, M. (2012). Exploring the influence of qualitative factors on the thermal comfort of office occupants. Architectural Science Review, 55(3), 169-175. doi:10.1080/00038628.2012.688014.

Leaman, A. (2012). Usable Buildings. Accessed 4/04/2014 from: http://www.usablebuildings.co.uk

CABE, (2004). The impact of office design on business performance. A report for Architecture \& the Built Environment and the British Council for Offices, May 2005. Accessed 24/04/2012 from: http://webarchive.nationalarchives.gov.uk/20110118095356/http:/www.cabe.org.uk/files/impa ct-office-design-full-research.pdf.

Lee, S., \& Brand, J. (2010). Can personal control over the physical environment ease distractions in office workplaces? Ergonomics, 53(3), 324-335. doi:10.1080/00140130903389019. 
Sensharma N., Woods J., \& Goodwin A. (1998). Relationships between the indoor environment and productivity: A literature review. ASHRAE Transactions. 104 (part 1A), pp 686-701.

Haynes, B. (2008). Office Productivity A Self Assessed Approach To Office Evaluation. Paper presented at the PRRES 14th Annual Conference. Accessed 9/10/2013 from: http://www.prres.net/papers/Haynes_Office_Productivity_A_Self_Assessed_Approach_To_O ffice Evaluation.pdf.

Abdou, O., Gamal, M. \& Abdou, A. (2006). Correlation between Indoor Environmental Quality and Productivity in Buildings. 19th International Association for people-environment studies. Alexandria, Egypt.

Frontczak, M. \& Wargocki, P. (2011). Literature survey on how different factors influence human comfort in indoor environments. Building and Environment, 46(4), 922-937.

Hauge, Å., Thomsen, J., \& Berker, T. (2011). User evaluations of energy efficient buildings: Literature review and further research. Advances in Building Energy Research, 5(1), 109-127. doi:10.1080/17512549.2011.582350.

Hróbjartsson, A. \& Norup, M. (2003). "The use of placebo interventions in medical practice--a national questionnaire survey of Danish clinicians". Evaluation \& the Health Professions 26 (2): 15365. doi:10.1177/0163278703026002002. PMID 12789709.

Rosenthal, R. (2004). Experimenter Expectancy Effect in Encyclopedia of social science research methods. Editors: Lewis-Beck M., Bryman A and Liao T. SAGE Publications Inc. 357-358.

Callegaro, M. (2008). Social Desirability: Encyclopedia of Survey Reasearch Methods. SAGE.

Yang, H., Chen, X., \& Zelinsky, G. (2009). A new look at novelty effects: Guiding search away from old distractors. Attention, Perception, \& Psychophysics 2009, 71 (3), 554-564 doi:10.3758/APP.71.3.554.

Levitt, S. \& List, J. (2007). What Do Laboratory Experiments Measuring Social Preferences Reveal about the Real World? The Journal of Economic Perspectives, 21(2), 153-174. doi: $10.2307 / 30033722$.

Levitt, S. \& List, J. (2011). Was There Really a Hawthorne Effect at the Hawthorne Plant? An Analysis of the Original Illumination Experiments. American Economic Journal: Applied Economics, 3(1), 224-238. doi:10.1257/app.3.1.224.

Kampschroer, K. \& Heerwagen, J. H. (2005). The strategic workplace: development and evaluation. Building Research \& Information, 33(4), 326-337. doi:10.1080/09613210500161976.

Baird, G. (2010). Sustainable Buildings in Practice: What the Users think: Routledge Taylor \& Francis Group, 2 Park Square, Milton Park, Abingdon, Oxon OX14 4RN.

Kaarlela-Tuomaala, A., Helenius, R., Keskinen, E., \& Hongisto, V. (2009). Effects of acoustic environment on work in private office rooms and open-plan offices - longitudinal study during relocation. [Comparative Study Research Support, Non-U.S. Gov't]. Ergonomics, 52(11), 1423-1444. doi:10.1080/00140130903154579.

Newsham, G., Brand, J., Donnelly, C., Veitch, J., Aries, M., \& Charles, K., (2009). Linking indoor environment conditions to job satisfaction: a field study, Building Research \& Information, $37: 2,129-147$.

Thomas, L. (2010). Evaluating design strategies, performance and occupant satisfaction: a low carbon office refurbishment. Building Research \& Information, 38(6), 610-624. doi:10.1080/09613218.2010.501654.

Kekäläinen P., Niemelä R., Tuomainen M., Kemppilä S., Palonen J., Riuttala H. \& Reijula, K. (2010). Effect of reduced summer indoor temperature on symptoms, perceived work environment and productivity in office work. Intelligent Buildings International, 2(4), 251-266. doi:10.3763/inbi.2010.0051.

Leaman, A. \& Bordass, B. (2007) Are building users more tolerant of Green buildings? Building Research \& Information, 35:6, 662-673, DOI: 10.1080/09613210701529518.

McCarney, R., Warner, J., Iliffe, S., van Haselen, R., Griffin, M. \& Fisher, P. (2007). "The Hawthorne Effect: a randomised, controlled trial". BMC Med Res Methodol 7: 30. doi:10.1186/14712288-7-30. PMC 1936999. PMID 17608932.

Tanabe, S., Iwahashi, Y., Tsushima, S., \& Nishihara, N. (2013). Thermal comfort and productivity in offices under mandatory electricity savings after the Great East Japan earthquake. Architectural Science Review, 1-10. doi:10.1080/00038628.2012.744296. 
Prakash, P. (2005). Effect of indoor environmental quality on occupant's perception of performance: A comparative study. Master of interior design Thesis, University of Florida 2005.

Baird, G., Leaman, A., \& Thompson, J. (2012). A comparison of the performance of sustainable buildings with conventional buildings from the point of view of the users. Architectural Science Review, 55(2), 135-144. doi:10.1080/00038628.2012.670699.

Lenoir, A., Baird, G. \& Garde, F. (2012). Post-occupancy evaluation and experimental feedback of a net zero-energy building in a tropical climate. Architectural Science Review, 55(3), 156-168. doi:10.1080/00038628.2012.702449.

Paevere, P., \& Brown, S. (2008). Indoor Environment Quality and Occupant Productivity in the CH2 Building: Post-Occupancy Summary. PO Box 56, Highett, VIC, 3190: CSIRO.

Hepner, C., \& Boser, R. (2006). Architects' Perceptions of LEED Indoor Environmental Quality Checklist Items on Employee Productivity. International Journal of Construction Education and Research, 2(3), 193-208. doi:10.1080/15578770600907156.

Roulet, C., Johner, N., Foradini, F., Bluyssen, P., Cox, C., De Oliveira Fernandes, E., \& Aizlewood, C. (2006). Perceived health and comfort in relation to energy use and building characteristics. Building Research \& Information, 34(5), 467-474. doi:10.1080/09613210600822279.

Lee, S. (2000). Understanding productivity improvement in a turbulent environment: A symposium introduction. Public Productivity \& Management Review, 23, 423-427.

Buttonwood, (2013). Technology and our standard of living: Are we really better off than the numbers show? The Economist. Accessed 9/10/2013 from: http://www.economist.com/blogs/buttonwood/2013/08/technology-and-our-standard-living .

Neely, A. (1998). Measuring Business Performance, Economist Books, London.

Oseland, N. (1999). Environmental Factors Affecting Office Worker Performance: A Review of Evidence, Technical Memoranda TM24: CIBSE, London.

Haynes, B. (2007c). An Evaluation of Office Productivity Measurement. Journal of Corporate Real Estate, 9(3), 144-154.

Pulakos, E. (2007) Performance measurement. Applied measurement: Industrial psychology in human resources management. Book Chapter by Whetzel D. \& Wheaton G. Mahwah, N.J. : Lawrence Erlbaum Associates, 2007 pg 293.

Woods, J. (2002). Research Protocols for Evaluating the Relationship between the Indoor Environment and Productivity: Final Report ASHRAE Research Project 700-RP. Atlanta, George 30329.

World Building Design Guide (WBDG) (2012). Productive. Productive Committee Accessed 9/10/2013 from: http://www.wbdg.org/design/productive.php .

Corporate Leadership Council, (1998). Utilizing Employee Opinion Surveys to Improve Business Performance, Washington: Corporate Executive Board.

Zhao, J., Zhu, N., \& Lu, S. (2009). Productivity model in hot and humid environment based on heat tolerance time analysis. Building and Environment, 44(11), 2202-2207. doi:10.1016/j.buildenv.2009.01.

Wharton, A. (2009). The Sociology of Emotional Labor. Annual Review of Sociology 34: 147-65.

Vischer, J. (2008). Towards an environmental Psychology of Workspace: How People are affected by Environments for Work. Architectural Science Review, 51(2), 97-108.

Huizenga, C., Abbaszadeh, S., Zagreus, L., \& Arens, E. (2006). Air Quality and Thermal Comfort in Office Buildings: Results of a Large Indoor Environmental Quality Survey. Proceedings, Healthy Buildings 2006, Vol. III, 393-397, Lisbon, Portugal, June.

Brager, S. \& Baker, L. (2009). Occupant satisfaction in mixed-mode buildings. Building Research \& Information, 37(4), 369-380. doi:10.1080/09613210902899785.

Leaman, A., \& Bordass, B. (2001). Assessing building performance in use 4: the Probe occupant surveys and their implications. Building Research \& Information, 29(2), 129-143. doi:10.1080/09613210010008045.

Pepler, R., \& Warner, R. (1968). Temperature and Learning: an experimental study. ASHRAE Transactions, 74(2), 11-19.

Roaf S. (2005). Closing the loop: Benchmarks for sustainable buildings. RIBA Publications, London.

Monfared, I. \& Sharples, S. (2011). Occupants' perceptions and expectations of a Green office building: a longitudinal case study. Architectural Science Review, 54(4), 344-355. doi:10.1080/00038628.2011.613636\#2011. 
Haynes, B. (2007b). The impact of the behavioural environment on office productivity. Journal of Facilities Management, 5(3), 158-171. doi:10.1108/14725960710775045.

Roethlisberger, F. \& Dickson, W. (1939). Management and the Worker. Cambridge, MA.: Havard Univeristy Press.

Chau, C., Leung, T., \& Law M. (2006). Importance of Being Connected to the Outside in the Workplace. Architectural Science Review, 49(1), 91-98. doi:10.3763/asre.2006.4911.

Brauer, C. \& Mikkelsen, S. (2010). The influence of individual and contextual psychosocial work factors on the perception of the indoor environment at work: a multilevel analysis. International Architectural Occupation Environment Health, 83(6), 639-651. doi:10.1007/s00420-010-0511-9.

Leblebici, D. (2012). Impact of Workplace Quality on Employees' Productivity: Case Study of a Bank In Turkey. Journal of Business, Economics \& Finance, 1(1), 38 - 49.

Meijer, E., Frings-Dresen, M. \& Sluiter, J. (2009). Effects of office innovation on office workers' health and performance. Ergonomics, 52(9), 1027-1038. doi:10.1080/00140130902842752.

Moshagen, M., Musch, J., \& Goritz, A. S. (2009). A blessing, not a curse: experimental evidence for beneficial effects of visual aesthetics on performance. Ergonomics, 52(10), 1311-1320. doi:10.1080/00140130903061717.

Smith, M., \& Bayehi, A. (2003). Do ergonomics improvements increase computer workers' productivity?: an intervention study in a call centre. [Comparative Study Research Support, U.S. Gov't, P.H.S.]. Ergonomics, 46(1-3), 3-18. doi:10.1080/00140130303522.

Onyeizu E \& Byrd H. (2014). Are IEQ factors more important to productivity than other factors in the workplace? 50th ASC Annual International Conference, March 26-28, 2014 Virginia, USA.

Kumar, S. \& Fisk, W. (2002) The Role of Emerging Energy-Efficient Technology in Promoting Workplace Productivity and Health1: Final Report. Lawrence Berkeley National Laboratory.. Accessed 11/4/2013 from: http://www.escholarship.org/uc/item/0sw558qr

Onyeizu, E. (2014) Can Architecture Increase Productivity? A Case of Green Buildings. PhD Thesis, The University of Auckland. 
Table 1: Self-evaluation studies on the relationship between IEQ and Productivity. Source: Author

\begin{tabular}{|c|c|c|c|c|c|}
\hline Year & Study & IEQ factor tested & Sample population & $\begin{array}{l}\text { Instrument(s) } \\
\text { applied }\end{array}$ & Findings \\
\hline 2001 & $\begin{array}{l}\text { Leaman } \\
\text { Bordass }\end{array}$ & $\begin{array}{l}\text { Temperature, lighting, } \\
\text { noise, air quality }\end{array}$ & Workers in UK office buildings & $\begin{array}{l}\text { BUS } \\
\text { questionnaire }\end{array}$ & $\begin{array}{l}\text { Noise level is most strongly associated with perceived productivity even though the } \\
\text { relationship is weak. }\end{array}$ \\
\hline 2005 & Prakash & $\begin{array}{l}\text { Temperature, } \\
\text { illuminance and noise }\end{array}$ & $\begin{array}{l}80 \text { occupants in a LEED and non- } \\
\text { LEED certified buildings. }\end{array}$ & $\begin{array}{l}\mathrm{CBE} \\
\text { questionnaire }\end{array}$ & $\begin{array}{l}\text { Occupants in the LEED certified building felt daylighting and thermal comfort had } \\
\text { positive effect on their productivity. Occupants in the Non-LEED certified building felt } \\
\text { that the good overall ambient of the building improved there productivity. }\end{array}$ \\
\hline 2006 & Hepner \& Boser & $\begin{array}{l}\text { All factors on LEED } \\
\text { IEQ checklist. }\end{array}$ & 55 Architects & $\begin{array}{l}\text { Web-based } \\
\text { Questionnaire }\end{array}$ & $\begin{array}{l}\text { Daylight and Views, Daylight for } 75 \% \text { of spaces most influence employee productivity } \\
\text { for an initial budgeted cost. }\end{array}$ \\
\hline 2006 & Roulet et al. & $\begin{array}{l}\text { Temperature, Noise, } \\
\text { Air quality, Lighting. }\end{array}$ & Occupants in 64 office buildings & Questionnaire & Perceived productivity correlated with temperature. \\
\hline 2008 & Haynes & $\begin{array}{l}\text { Temperature, lighting, } \\
\text { noise, ventilation, air } \\
\text { quality }\end{array}$ & 996 workers in office buildings. & Questionnaire & $\begin{array}{l}\text { Physical components of comfort were not enhancing perceived productivity. Rather, } \\
\text { interaction and distraction had an effect on perceived productivity. }\end{array}$ \\
\hline 2008 & $\begin{array}{l}\text { Paevere } \\
\text { Brown }\end{array}$ & $\begin{array}{l}\text { Temperature, air } \\
\text { quality, noise and } \\
\text { lighting }\end{array}$ & $\begin{array}{l}\text { Occupants of Council House } 2 \text { in } \\
\text { Melbourne }\end{array}$ & $\begin{array}{l}\text { BUS } \\
\text { questionnaire } \\
\text { and focus } \\
\text { group } \\
\text { interviews. }\end{array}$ & $\begin{array}{l}4.9 \% \text { increase in staff productivity due to improved IEQ. Focus group interviews } \\
\text { highlighted the difficulty of distinguishing between building-related impacts on } \\
\text { productivity from other factors such as workplace restructuring. }\end{array}$ \\
\hline 2009 & $\begin{array}{l}\text { Kaarlela- } \\
\text { Tuomaala et al. }\end{array}$ & Noise & $\begin{array}{l}31 \text { workers who moved from a } \\
\text { private office room to open-plan } \\
\text { office }\end{array}$ & Questionnaire & $\begin{array}{l}\text { Significant correlation between noise levels and productivity of workers. The authors } \\
\text { concluded that an open plan office is not recommended for professional workers. }\end{array}$ \\
\hline 2009 & Newsham et al. & $\begin{array}{l}\text { Lighting, noise, } \\
\text { ventilation }\end{array}$ & $\begin{array}{l}100 \text { occupants in an open-plan } \\
\text { office building in Michigan, USA. }\end{array}$ & Questionnaire & $\begin{array}{l}\text { Significant link between overall environmental satisfaction and job satisfaction. } \\
\text { However, no correlation was found for lighting, acoustics, ventilation and job stress. }\end{array}$ \\
\hline 2009 & $\begin{array}{l}\text { Hameed } \\
\text { Amjad }\end{array}$ & $\begin{array}{l}\text { Noise, lighting and } \\
\text { temperature }\end{array}$ & $\begin{array}{l}105 \text { employees in } 13 \text { banks in } \\
\text { Pakistan }\end{array}$ & Questionnaire & Lighting most affected the productivity of workers \\
\hline 2010 & Baird & $\begin{array}{l}\text { Temperature, lighting, } \\
\text { noise, air quality }\end{array}$ & $\begin{array}{l}\text { Occupants of } 30 \text { Green certified } \\
\text { buildings around the world }\end{array}$ & $\begin{array}{l}\text { BUS } \\
\text { questionnaire } \\
\text { and interviews }\end{array}$ & Significant increase in productivity associated with Green IEQ. \\
\hline 2010 & Grady et al. & $\begin{array}{l}\text { Air quality, } \\
\text { temperature, } \\
\text { humidity, ventilation, } \\
\text { lighting, noise }\end{array}$ & $\begin{array}{l}175 \text { employees of a LEED certified } \\
\text { office building. }\end{array}$ & Questionnaire & Reductions in absenteeism and work hours as a result of improved IEQ \\
\hline 2010 & Thomas & $\begin{array}{l}\text { Air } \\
\text { temperature, lighting } \\
\text { and noise }\end{array}$ & $\begin{array}{l}\text { Occupants of a low carbon office } \\
\text { refurbishment in Sydney, Australia }\end{array}$ & $\begin{array}{l}\text { BUS } \\
\text { questionnaire }\end{array}$ & $7.21 \%$ increase in productivity as a result of environmental conditions in the building. \\
\hline 2010 & $\begin{array}{l}\text { Kekalainen et } \\
\text { al. }\end{array}$ & $\begin{array}{l}\text { Summer indoor } \\
\text { temperature }\end{array}$ & $\begin{array}{l}\text { Occupants of an office building in } \\
\text { Helsinki, Finland }\end{array}$ & Questionnaire & $\begin{array}{l}\text { Work efficiency increased after renovation of a HAVC system in the office. } 4.4 \% \\
\text { improvement was reported. }\end{array}$ \\
\hline 2010 & Lee \& Brand & $\begin{array}{l}\text { Personal control over } \\
\text { physical environment }\end{array}$ & $\begin{array}{l}384 \text { employees in corporate office } \\
\text { of } 3 \text { manufacturing companies in }\end{array}$ & Questionnaire & $\begin{array}{l}\text { The perception of control over aspects of the physical environment mediated the } \\
\text { relationship between perceived job performances. }\end{array}$ \\
\hline
\end{tabular}




\begin{tabular}{|c|c|c|c|c|c|}
\hline & & & Michigan, USA & & \\
\hline 2010 & Drake et al. & Temperature & $\begin{array}{l}\text { Staff in air conditioned and } \\
\text { naturally ventilated office buildings }\end{array}$ & Questionnaire & $\begin{array}{l}\text { Productivity of occupants in Air conditioned building decreased by }-0.5 \% \text { while } \\
\text { occupants in the naturally ventilated building perceived no change in their productivity. }\end{array}$ \\
\hline 2010 & $\begin{array}{l}\text { Brauer } \quad \& \\
\text { Mikkelsen }\end{array}$ & $\begin{array}{l}\text { Temperature, noise, } \\
\text { lighting, air quality }\end{array}$ & 3,281 employees in 39 workplaces. & Questionnaire & Importance of psychosocial work environment at an individual level on performance. \\
\hline 2011 & Zhang et al. & $\begin{array}{l}\text { Temperature and Air } \\
\text { quality }\end{array}$ & 72 buildings in ASHRAE database & Questionnaire & No obvious best temperature for productivity \\
\hline 2011 & $\begin{array}{l}\text { Monfared \& } \\
\text { Sharples }\end{array}$ & All IEQ factors & $\begin{array}{l}\text { Occupants in two Green UK } \\
\text { government office buildings. }\end{array}$ & Questionnaire & $\begin{array}{l}\text { Green identity of the buildings had a greater influence on the occupants' perception than } \\
\text { IEQ in the buildings. }\end{array}$ \\
\hline 2012 & $\begin{array}{l}\text { Baird \& } \\
\text { Thompson }\end{array}$ & Lighting & $\begin{array}{l}2540 \text { occupants of } 36 \text { commercial } \\
\text { and institutional buildings. }\end{array}$ & $\begin{array}{l}\text { BUS } \\
\text { questionnaire }\end{array}$ & A correlation was found between lighting and productivity of occupants. \\
\hline 2012 & Baird et al. & $\begin{array}{l}\text { Temperature, lighting, } \\
\text { noise and air quality }\end{array}$ & $\begin{array}{l}\text { Occupants of } 31 \text { Green certified } \\
\text { buildings and } 109 \text { conventional } \\
\text { buildings }\end{array}$ & $\begin{array}{l}\text { BUS } \\
\text { questionnaire }\end{array}$ & $\begin{array}{l}\text { Occupants of green certified buildings reported higher productivity than those in } \\
\text { conventional buildings as a result of the IEQ. }\end{array}$ \\
\hline 2012 & Lenoir et al. & $\begin{array}{l}\text { Temperature, lighting, } \\
\text { noise and air quality }\end{array}$ & $\begin{array}{l}\text { Staff and students in the ENERPOS } \\
\text { building in La Reunion }\end{array}$ & $\begin{array}{l}\text { BUS } \\
\text { questionnaire } \\
\text { and interview }\end{array}$ & $\begin{array}{l}\text { Students reported an average of } 11.25 \% \text { increase in productivity while staff reported an } \\
\text { average of } 17.5 \% \text { as result of the better IEQ in the mixed-mode air conditioned building. }\end{array}$ \\
\hline 2012 & Mak \& Lui & Sound & $\begin{array}{l}259 \text { office workers in } 38 \text { air- } \\
\text { conditioned offices in Hong Kong. }\end{array}$ & Questionnaire & Significant correlation between noise, temperature and productivity. \\
\hline 2012 & $\begin{array}{l}\text { McCunn } \\
\text { Gifford }\end{array}$ & Green IEQ attributes & $\begin{array}{l}77 \text { employees in } 15 \text { public and } \\
\text { private sector office buildings. }\end{array}$ & Questionnaire & $\begin{array}{l}\text { No positive correlation was found between Green design attributes and Occupant } \\
\text { productivity. }\end{array}$ \\
\hline 2012 & $\begin{array}{l}\text { Healey } \quad \& \\
\text { Webster- } \\
\text { Mannison }\end{array}$ & Temperature & $\begin{array}{l}9 \text { office workers in an architectural } \\
\text { design practice - pilot study }\end{array}$ & $\begin{array}{l}\text { Semi- } \\
\text { structured } \\
\text { interview }\end{array}$ & $\begin{array}{l}\text { Highlighted the importance of cultural and contextual factors that influence comfort- } \\
\text { related adaptation. }\end{array}$ \\
\hline 2013 & Tanabe et al. & $\begin{array}{l}\text { Temperature, lighting, } \\
\text { ventilation }\end{array}$ & $\begin{array}{l}\text { Occupants of five office buildings } \\
\text { in Tokyo }\end{array}$ & $\begin{array}{l}\text { CBE } \\
\text { questionnaire }\end{array}$ & $\begin{array}{l}\text { Productivity decreased by } 6.6 \% \text { when electricity saving measure was introduced - } \\
\text { controlled relative humidity within a narrow range }(46 \% \& 60 \%) \text {. The authors noted that } \\
\text { loss of productivity could not purely be the result of environmental conditions. }\end{array}$ \\
\hline 2013 & $\begin{array}{l}\text { Kim and de } \\
\text { Dear }\end{array}$ & Various IEQ factors & $\begin{array}{l}\text { POE database of } 42,764 \\
\text { respondents in } 303 \text { office buildings. }\end{array}$ & $\begin{array}{l}\text { CBE } \\
\text { questionnaire }\end{array}$ & $\begin{array}{l}\text { Noise level and visual privacy affected workspace satisfaction which is closely related to } \\
\text { perceived productivity }\end{array}$ \\
\hline
\end{tabular}


Abstract

Purpose - The purpose of this literature review is to investigate the reliability of self-evaluation as a method for measuring the effect(s) of IEQ on the productivity of office workers. The aim of this review is to identify the various constraints to its adequacy in measuring productivity.

Design/methodology/approach - Thirty (30) studies were selected from peer-reviewed sources and reviewed on their method of measuring productivity. These studies employed the use of self-evaluation (questionnaires or interview) as the sole method of measuring the effect of IEQ on productivity/performance.

Findings - This review provides insight on the insufficiencies and biases prevalent in self-evaluation. Various issues that compromised the reliability of self-evaluation results in an office environment were discussed. We concluded that self-evaluation is not reliable and does not accurately measure occupant productivity.

Research limitations/implications - This study has been a review of past studies and their findings. Further studies that will provide empirical evidence is required to solely test the reliability of self -evaluation in measuring productivity and the effect of factors such as IEQ on it.

Practical implications - The paper calls for further debate on occupant's productivity measurement and how the various factors that affect it can be quantified into measurable entities.

Originality/value - This paper fulfils an identified need to revisit the technique of self-evaluation as a method for measuring occupant's productivity.

\section{Introduction}

Building performance concerning indoor environment quality (IEQ) has gained increasing attention in recent years. The fact that people spend around $90 \%$ of their time indoors (Klepeis et al., 2001) has made the implications of the indoor environment imperative to designers. There is evidence towards a consensus view that the IEQ conditions that result in comfort do, in fact, increase the productivity of occupants (Lan and Lain, 2009; Hameed and Amjad, 2009; Liu et al., 2010; Kekalainen et al., 2010). However, recent studies have findings that indicate that there is no causal link between occupant productivity and IEQ (Zhang et al., 2011; Mak and Lui, 2012; McCunn and Gifford, 2012; Healey and Webster-Mannison, 2012) in office environments. But this assumes that the methods of measuring productivity have validity. Perception study, expressly questionnaires and interviews that ask occupants to evaluate their perceived productivity (Leaman, 2012) is a conventional method that has been used to measure the cognitive performance of workers. A literature review carried out by Onyeizu (2015) wherein the author review past works on the relationship between IEQ and occupant productivity in Green office spaces showed that majority of studies in this subject area had employed the use of self-evaluated productivity (questionnaires or interviews) as their method of investigation.

Leaman and Bordass (2007) stated that "in buildings, people are the best measuring instruments: they are just harder to calibrate." As such, most studies depend on self-evaluation as the way to capture information. While interviews are more rigorous and demand a direct communication between the interviewer and the person interviewed, questionnaires are typically less in-depth and cover a larger population within a short time frame. Also, interviews can distort user-response since they raise the anticipation level of the respondents who can be prone to responding with answers that they anticipate will 'please' the interviewer (similar to the Hawthorne effect (McCarney et al., 2007). Hence, various questionnaires are employed in Post Occupancy Evaluations (POE) with the aim of obtaining feedback from occupants concerning the performance of their buildings. Popular examples are the Center for the Built Environment (CBE) (Zagreus et al., 2004) and Building in Use Survey (BUS) questionnaires (Leaman, 2012). But then, how reliable is a self-evaluated productivity in measuring the performance of workers in the office environment?

Measuring how productive an office worker is on a day to day activity for an average working period remains a subject of debate (CABE, 2004; Lee and Brand, 2010). Senshama et al., (1998) noted that there are gaps in existing knowledge about non-industrial productivity measurement and claim that current literature presents contradictory evidence about links between human responses and occupant productivity. Haynes (2008) identified 
the measure of productivity and the effects of the office environment on the productivity of occupants as two main areas that require further research. In the absence of a test that can directly relate increased monetary gain to the achievement of environmental criteria, research into productivity needs to focus on a) whether the environmental standards are appropriate and $\mathrm{b}$ ) whether the tests for productivity are relevant and robust.

The purpose of this paper is to assess the sufficiency of self-evaluated productivity in measuring the effect of IEQ on productivity in offices through a review of literature on the potential bias and their effects on the validity of results. Previous literature reviews on IEQ and occupant productivity (Abdou et al., 2006; Frontczak and Wargocki, 2011; Hauge et al., 2011) have concentrated on finding absolute effects of physical and non-physical components of IEQ on occupant comfort and satisfaction that can be related to productivity. Such reviews have been equivocal in their support for the claim that IEQ is responsible for productivity, but none of them critically examined the measurement methods involved. There is the need to review self-evaluation as a method for productivity assessment and establish its strengths and weaknesses in this area of research. It is important to point out that this article does not address the effect of the specification of internal materials, cleanliness or maintenance (Kumar and Fisk, 2002) on comfort, health, and productivity.

\section{Methodology}

. The objective of the review is to highlight issues associated with self-evaluation and barriers to its insufficiency in capturing occupant productivity in its totality. The literature reviewed includes referred journal and conference papers. A review of available literature was carried out on the subject of perceptions studies and self-evaluation as well as occupant performance in the office environment. A search of keywords: performance, indoor environment quality, productivity, questionnaire, and interview was carried out through Google Scholar and Science Direct engines for studies published after the year 2000 to reflect the current state of the art in research and its relevance in this field. Studies that employed the use of self-evaluation (questionnaires or interview) as the sole method of measuring the effect of IEQ on productivity/performance were selected. It was also important that these studies are from peer reviewed sources. The bibliographies of collected articles were examined to identify relevant articles that might have been missed during the search.

Thirty (30) studies were found to be of importance to this review. While most of the studies found a causal link between IEQ and productivity, others used productivity as the criterion to determine thresholds for comfort or satisfaction.

\section{Results}

Table I provides basic information on each study reviewed. All the studies use questionnaires and/or interview as their method of measuring the effect of IEQ on productivity. The studies reviewed were found to focus mainly on IEQ factors such as Temperature, Noise, Indoor Air Quality, Lighting and Personal control over IEQ factors in the office environment. As shown in Figure 1,35\% of the studies found a correlation between overall IEQ and perceived productivity while $17 \%$ found on significant correlation. $15 \%$ felt Noise was correlated with productivity and $12 \%$ perceived Temperature as an influencing factor. This is followed by Lighting (9\%), IAQ (6\%) and Visual Privacy and Control over IEQ (3\%).

A brief summary of each study and their findings is presented in section 3.1highlighting their methodology and findings. The potential biases found to be associated with these studies are discussed in section 3.2. The aim is to illustrate the degree of effect these bias can have on study results as well as their significance in an area of research that has much influence on office design and productivity. While each potential bias might not be associated with all of the studies, it is assumed that more association is possible given that more information on each study is obtainable.

Section 4 brings to light certain issues that limit the measurement of productivity in a work environment. These issues are discussed in relation to their impact o the validity of self-evaluated effects of IEQ on productivity. The intention of this paper is not to discredit the science behind perception study or make light the contributions selfevaluation has made to research especially in areas such as post-occupancy evaluation of buildings. Rather, it is to highlight the insufficiency of self-evaluation as a sole method for measuring occupant productivity (cognitive performance) and the influence of IEQ on it. 


\subsection{Summary of findings from literature}

The authors acknowledge that there may be some studies related to this area that has not been identified in this paper. However, the studies reviewed in this paper are regarded to be representatives of the research in this field. The findings of these studies are summarised below.

Leaman and Bordass (2001) employed the use of a Building in Use Survey (BUS) questionnaire to study the effect of IEQ on perceived performance of workers in UK office buildings. The authors found that noise levels (in particular random noise or irrelevant conversation) were the environmental factor most strongly associated with perceived productivity, even though the relationship is weak. They also found that occupants who perceived that they were comfortable with the IEQ in their buildings tended to say that they were more productive than their colleagues.

Prakash (2005) compared the effect of IEQ found in a LEED certified building with that found in a non-LEED certified building. The researcher administered a web-based Center for the Built Environment (CBE) questionnaire to 80 occupants of each building. The author found that occupants of the LEED certified buildings felt that daylighting and thermal comfort had a positive effect on the occupants' perception of productivity. On the other hand, the occupants in the non-LEED certified building felt that their productivity was affected by the good overall ambience of the building and the fact that the building facilitated multiple activities.

Roulet et al., (2006) assessed occupants' satisfaction with comfort in sixty-four (64) office buildings in nine (9) European countries with questionnaires. They observed that the perceived productivity of occupants correlated with temperature in the summer and was less obvious in the winter. The occupants reported that overly high temperatures in summer decreased their productivity.

Kim and Kim (2007) examined the influence of fluctuating light levels on visual perception. The aim of the experiment was to determine acceptable tolerance ranges of light changes. Productivity was assessed through questionnaires on visual responses under constant illuminance conditions and annoyance tests under fluctuating illuminance conditions. The authors found that fluctuations in the illuminance conditions did not significantly influence reading task performance and letter identification performance.

Haynes (2008) carried out a paper-based questionnaire survey on 996 workers in 26 offices and an online questionnaire on 422 office workers. The IEQ factors (termed physical component of comfort in this study) tested in this study were ventilation, heating, natural lighting, artificial lighting, décor, cleanliness, overall comfort, and physical security. The author compared these factors with other factors such as office layout, interaction and distraction. He observed that these physical components of comfort were not enhancing occupants' perceived productivity. Rather, interaction and distraction were found to have an effect on perceived productivity.

Paevere \& Brown (2008) observed a 4.9\% increase in staff productivity due to improved IEQ in a post-occupancy evaluation carried out on newly completed Council House 2 located in Melbourne. They also reported that $75 \%$ of the building occupants rated that building as having a positive or neutral effect on their productivity. Using the BUS questionnaire, this survey was based on the occupants' perception of productivity. An interesting finding in this survey was that the focus group interviews carried out parallel to the BUS questionnaire highlighted the difficulty of distinguishing between building-related impacts on productivity from other factors such as workplace restructuring.

Lee and Kim (2008) noted that LEED-certified buildings had higher occupant performance in thermal comfort and IAQ while Non-LEED-certified buildings showed higher occupant performance in lighting and acoustic quality. The authors analysed occupants' responses to the effect of IEQ factors on their performance from CBE database containing 15 LEED-certified buildings and 200 non-LEED-certified buildings.

Kaarlela-Tuomaala, et al., (2009) used questionnaires to study 31 workers who moved from a private office room to open-plan offices before and after relocation. The results showed that the average noise level on a working day increased significantly and this affected the perceived productivity of the occupants. The negative effects observed included increased distraction, reduced privacy, increased concentration difficulties and increased use of coping strategies. The authors concluded that an open-plan office should not be recommended for professional workers. 
Newsham et al., (2009) found a significant link between overall environmental satisfaction and job satisfaction through a questionnaire survey carried out on 100 occupants in an open-plan office building in Michigan, USA. While the authors pointed out that better indoor environments play a role in elevating job satisfaction, they also observed that there was no significant correlation between job satisfaction with lighting, acoustics and ventilation, and job stress.

Hameed \& Amjad (2009) deduced from their survey of 105 employees in 13 banks in Pakistan that there is a direct relationship between office design and productivity. They carried out a questionnaire survey and found that lighting was the prime factor which affected productivity. Noise, lighting and temperature were also found to have an effect on productivity.

Baird (2010) used the BUS questionnaire to measure occupants' perception of their productivity on the environmental conditions in their office space. The work was a five-year POE project on the 'performance in practise from occupants' perception' of 30 commercial and institutional sustainable buildings in the world. The productivity of the occupants was found to have increased by an average of $4.07 \%$. However, the author observed a high ratio between negative and positive comments on the IEQ factors in the buildings (2.25:1).

Grady et al., (2010) found a direct effect of IEQ on productivity by $2.6 \%$ (increase) while studying the health and productivity benefits of moving from conventional to Green office buildings on occupants. Pre-move and postmove questionnaire surveys were conducted on 175 employees of conventional office buildings who moved to LEED-certified office buildings. The authors noted an additional 38.98 work hours per occupant in a year as a benefit of Green office buildings.

Thomas (2010) stated that buildings that fail to deliver in terms of indoor environment quality have been noted to affect occupants' productivity. In his research on occupant satisfaction with a low carbon office refurbishment in Sydney, Australia, the authors noted that the occupants perceived their productivity to have increased by $7.21 \%$ as a result of the environmental conditions of the building. The researcher employed the BUS questionnaire to obtain the perceived productivity ratings from the occupants.

Kekäläinen et al., (2010) studied the effects of reduced summer indoor temperature on perceived productivity through the renovation of an HVAC system in an office building located in Helsinki, Finland. The occupants' productivity was measured using two questionnaire surveys on work efficiency and psychosocial work environment. It was observed that work efficiency was perceived to decrease before the renovation and improved significantly after the renovation.

Lee \& Brand (2010) analysed 384 questionnaires collected from employees in the corporate offices of three (3) manufacturing companies in Michigan, USA. The researchers observed that the perception of control over aspects of the physical environment mediated the relationship between perceived distractions and perceived job performance. In this case, a sense of control over the physical environment factors had a mediating influence between work attitudes and work outcomes.

Drake et al., (2010) studied the effects of two environmental control modes on occupants' comfort and productivity in two (2) mixed mode (MM) office buildings. The first study building was made up of features that gave occupants the option to choose between an air-conditioned mode (AC) and a natural ventilation mode (NV) depending on the outdoor weather conditions. The second study building consisted of a Building Management System (BMS) that switched from NV to AC depending on the indoor temperature and outdoor weather. The study was carried out with a questionnaire. At the end of the study, the authors found that perceived productivity of occupants in the air-conditioned mode decreased (- 0.5\%), whereas those in the natural ventilation mode perceived no change in their productivity. They also found that the productivity of occupants in naturally ventilated offices did not improve as a result of the IEQ in the offices.

Brauer \& Mikkelsen (2010) used questionnaires to record the perception of 3,281 employees in 39 workplaces regarding the indoor environment of their offices. They observed the importance of psychosocial work environment factors at an individual level on performance. 
Zhang, et al., (2011) examined the relationship between temperature thresholds and productivity using the ASHRAE field study database. The analysis was conducted on 72 buildings in the database. The authors found that there is no obvious best temperature for productivity.

Monfared \& Sharples (2011) studied occupants in two new Green UK government office buildings over a 2-year period. The authors observed that the Green identity of the buildings had a greater influence on occupants' perception than the environmental conditions in the buildings. Irrespective of the close similarity of one of the studied Green-certified buildings to a conventional building, the occupants reported high satisfaction with the IEQ of the Green building.

Kamaruzzaman and Sabrani (2011) analysed occupants' perception of the effect of IAQ on their performance. Questionnaires were distributed to occupants of four (4) office buildings. Analysis of the results showed that the increment of work productivity due to the effect of IAQ was slightly low.

Baird \& Thompson (2012) observed a correlation between lighting and productivity. Using the BUS questionnaire, the authors studied occupants' perception of the IEQ in their indoor environment and found that lighting affects productivity. They tested four aspects of lighting - Lighting overall, Natural light, Artificial light, Glare from the sun and sky and Glare from lights.

Baird et al., (2012) also used the BUS questionnaire to retrieve data on perceived productivity. The authors compared the perception of occupants of 31 Green-certified buildings and 109 conventional buildings worldwide. In terms of their perceived productivity, it was found that productivity in Green buildings was higher than in the conventional buildings as a result of the IEQ. The IEQ factors investigated were lighting, temperature, noise and air quality.

Using both questionnaire and interview, Lenoir et al., (2012) measured the productivity of staff in the ENERPOS building located in the French tropical island of La Reunion in the Indian Ocean. A BUS questionnaire was given to the staff and students occupying this building. While the students reported an average increase in productivity of $11.25 \%$, the staff reported an average $17.5 \%$ increase in productivity. A similar result was obtained during interview sessions as all the interviewed occupants perceived an improvement in their productivity as a result of the better IEQ in this mixed-mode air-conditioned building.

Mak \& Lui (2012) carried out a questionnaire survey of 259 office workers in 38 air-conditioned offices in Hong Kong. They found a strong and significant correlation between both noise and temperature, and the productivity of the occupants. The types of noise that resulted in low productivity were identified as background noise, closing doors, human activity and noise from inside and outside the office. They also found that lighting and office layout had a secondary influence on productivity.

McCunn \& Gifford (2012) noted that Green designs in office buildings do not have a positive effect on employee engagement or any environmental attitudes and behaviours. The researchers studied 77 employees in 15 public and private sector office buildings in a medium-sized Canadian city. The data collected from the questionnaire survey showed that the employees' office impressions were significantly negatively correlated with the number of Green design attributes. The only attributes that concerned employees were "having enough access to windows" and "enough decoration and aesthetical appeal inside the office". There was no positive correlation found between Green design attributes and occupant productivity.

Healey \& Webster-Mannison (2012) used perceived productivity as the deciding factor in measuring thermal environmental satisfaction when the IEQ began affecting the participants' ability to carry out their work at a satisfactory rate. The pilot study was carried out at a small professional office of nine people operating an architectural design practice in a residential area of suburban Brisbane. The results highlighted the importance of cultural and contextual factors (qualitative) that facilitate or limit comfort-related adaptions.

Tanabe et al., (2013) used the CBE questionnaire to investigate thermal comfort and productivity in offices during mandatory electricity saving implementation. This survey was carried out in five office buildings in Tokyo under controlled temperature, illumination and ventilation levels. They found that when the electricity-saving measure was introduced the productivity of the workers decreased by $6.6 \%$. Presumably, the electricity saving measure 
changed the IEQ in the office, which affected the productivity of workers. However, the authors mentioned that the loss of productivity observed in their study could not be purely as a result of the environmental conditions as there were other reasons for the reduced productivity.

Annika et al., (2013) found that the correlation between IEQ and productivity was not statistically significant in their survey of 1,500 employees in 18 office buildings. The authors employed the use of questionnaires and interview as instruments of investigation.

Mulville et al., (2016) investigated the impact of the ambient environment on perceived comfort, health, wellbeing and by extension productivity on occupants of an open plan office. The occupants were situated in 30 workstations comprising on individual and group work desks. The authors employed the use of questionnaires while monitoring the environmental conditions. They found that there may be a hierarchy of the influence of IEQ factors. Noise levels were found to be of particular importance to comfort, health, wellbeing and thus, productivity. It was also found that occupant behaviour had a significant influence on comfort and wellbeing.

We can see from the review done above that there are contradicting findings on the relationship between IEQ and productivity. This indicates possible limitations in self-evaluation surveys. These limitations are discussed in section 3.2 below.

\subsection{Potential bias related to studies}

Human research is potentially affected by bias. This effect results from the fact that people's desires, preferences, and perceptions are subject to change. They are also affected by numerous factors including culture, trends, and biological makeup. Some sources of bias have been identified over the years of research to have a substantial influence on occupant's perceptions and judgements of their environment. They may distort the outcome of research and result in diverging outcomes. These biases are discussed further below.

1 Hawthorne effect: The Hawthorne effect occurs when a study outcome is affected by the mere knowledge of being under observation (McCarney et al., 2007). The Hawthorne effect was first noted by two engineers in 1924 in an experiment that tested the effects of lighting and salary on worker productivity (Levitt and List, 2007). Over the years, this effect has had an enormous impact on research and is a prominent source of bias in field studies (Levitt and List, 2011; Kampschroer and Heerwagen, 2005). According to Haynes (2007), it has also been influential in suggesting the effect of factors other than IEQ on productivity.

However, this effect may not be easy to eliminate since most of the time participants of field studies are aware of the study conducted on them. The mere fact of participation in the study (Levitt and List, 2007) is a reminder to the participants of the intention of the study (Levitt and List, 2011) especially for questionnaires and interviews surveys. For instance, the ethical requirement for human-related studies requires that participants are duly notified of the study to be conducted and accept to participate in it. As such, it can be assumed that all the participants of the studies reviewed in this paper (studies 1-30) were aware of the intention of the study. Thus, possible bias is created with the process and authenticity of the data collected.

2. Placebo effect: The Placebo effect is related to the perceptions and expectations of the study participant (Hrobjartsson \& Norup, 2003). If the participant expects an aspect of the physical environment to affect his/her productivity, it is likely that the participant will respond to this expectation. As it is with the medical placebo treatment, an effect of IEQ can be perceived even though it is non-existent. This effect can be found in studies where participants are examined on variables they have a preconceived perception or expectation about; even when it is not the intention of the researcher to initiate such effects.

For example, in this case of study 19 (Monfared \& Sharples, 2011) wherein the authors observed the influence of the building's Green identity on occupants perception of IEQ, the mere knowledge of the Green status of the study building influenced the perception of the occupants. This finding supports Hidalago and Hernandez (2001)'s "place identity theory", which predicts that people who are more sympathetic to environmental issues are more likely to give further credits to Green-certified buildings.

3. Experimenter expectancy effect: In the case of the experimenter expectancy effect, the researcher's cognitive bias on the study influences its outcome (Rosenthal, 2004). Though this effect might be an unconscious 
act, it is quite evident in a majority of questionnaire and interview-based studies. The type and nature of questions asked to a participant can be leading and suggest the direction of result expected. For example, the questionnaire used in studies 1, 6, 13, etc. asks the question "Please estimate how you think your productivity at work is decreased or increased by the environmental conditions in the building", it is possible that the respondents will state an increase as long as the environmental conditions are within an acceptable range and do not negatively impact on their comfort. While this question might not be intended to mislead, it is unlikely that respondents will rate $0 \%$ if the environmental conditions have not increased his productivity. This question can only be answered if the respondent has been in a previous building with worse indoor environment quality and can compare the two conditions.

On another note, productivity is a sensitive issue especially for an employee who is trying to prove him or herself worthy of his jo expectations. As such, the likelihood that an employee will state that his/her productivity hasn't increased is little. Such an instance could explain why in study 11, the author noted that occupants reported high number of negative comments about the environmental conditions in their building even though they rated their productivity to have significantly increased. Could it be that it is the undesirability of the environmental conditions that increased the productivity of these occupants?

4 Social desirability: Another source of bias is that of social desirability which is mostly found in questionnaire surveys (Callegaro, 2008). This bias describes the tendency of respondents to answer questions in a manner that will be viewed sympathetically by others. Most questionnaires are distributed to occupants in a building that either has an open plan space or offices with two-four occupants (studies 8, 9, 30 etc.) where there is possible communication amongst the occupants. It is impossible to know for sure that answers given to questions are valid and have not been affected by what other occupants think or the general perception amongst co-workers even if the respondent has not experienced such an effect personally.

The likelihood of this effect increases if questionnaires are filled out at lunch time or are not collected until the next day. For example, the questionnaires used in studies 6,10, 12 and 21 allows collection of filled out questionnaires 2 or 3 days after handout to provide adequate time for the respondents. In study 20 (Kamaruzzaman \& Sabrani, 2011), questionnaires were collected between $4-10$ days after handout.

$5 \quad$ Novelty effect: The novelty effect is most evident in intervention studies where the effect of change is investigated (Yang et al., 2009). An example is the effect of office renovation or movement from an old office building to a new one or the introduction of new technologies (e.g. studies 8,13 ). There is the tendency of an increase in productivity to be observed as a result of the introduction of a new product or technology, not because of the actual effect but due to an interest in the introduced product. People tend to patronise a new product not because the new product is better than the old but as a result of curiosity. For instance, the introduction of new furniture, a new lighting system and even a new HVAC in an office space can have an influence on the productivity of occupants. In this case, the increase in productivity whether it is reported or observed might be a function of the novelty of the work environment or equipment and not a function of an actual improvement due to the efficiency of the environment. People might want to go to work just because they have a new "cool" environment to work in. The downside of the novelty effect is that it is likely to be temporary. Its effect will wear off when the occupants become accustomed to the environment.

6 Perceived Productivity: The common trait between interviews and questionnaires is that the respondent (usually the occupant) is expected to make a judgment based on his/her experience with the IEQ of the study building and thus rate if his/her productivity has increased or decreased. In other words, if they felt that by increasing the temperature or lighting in the room that their productivity increased or decreased, they were expected to say so through the questionnaire or during the interview. The problem with this is that this only measures perceived productivity which is limited by the various sources of bias discussed earlier in this paper; not an actual and quantifiable productivity. Another issue lies with understanding what the word "productivity" means to occupants and how they measure a change in productivity (Onyeizu, 2014). As a universal definition and of productivity is yet to be obtained (discussed further in section 4) one wonders how an occupant can accurately measure a change in productivity that is a result of environmental factors. Self-evaluation cannot be a dependable substitute for an actual assessment of productivity especially. As Vischer (2008) suggested, a clearer distinction 
needs to be made between measuring user perceptions and judgments and measuring actual behavioural effects that are attributable to physical features.

\section{$7 \quad$ The error of singular questions}

A problem with the use of questionnaires is what that can be termed 'singular question'. This term is employed in this paper to describe a question that seems to represent several aspects of a topic. A singular question does not identify the various dimensions of the subject investigated but assumes that these aspects are represented in the question. For instance, if the singular question uses the word 'productivity', there is no provision to know what the respondents understand productivity to be and how they will measure it. This can be found in the questionnaires used in studies $11,13,21$, etc. Also, the response to singular questions is usually closed-ended which requires the respondent to select a reply from a list provided. Singular questions have the possibility of robbing the respondent of many options since one can only answer the question asked.

While all of these sources of bias might not be evident in all studies, some of them have influenced research outcomes which might be a reason for the conflicting or erroneous results on the subject of IEQ and occupant productivity in office buildings. These factors are constantly in play and can pose challenges to the validity of findings.

\section{Measuring productivity in the office environment}

In this section, we look into the various issues that can limit the accurate measurement of occupant productivity in an office environment. The issues discussed are inherent in a typical working environment making it a complicated process to identify how external factors affect productivity.

\subsection{Defining Productivity}

Occupant productivity has been described as a complex phenomenon influenced by many factors (Lee, 2000; Buttonwood, 2013). A review of studies on the effects of environment on productivity concluded that confusion about what productivity means has made it difficult to identify how environmental conditions affect worker performance (CABE, 2004). Oseland (1999) also acknowledged the complexity of measuring inputs and outputs, especially in today's modern office. This problem is aggravated in the case of employees whose activities are human related. Most products of business organisations such as customer satisfaction and knowledge are not quantifiable and cannot be represented in numbers/values.

However, there have been attempts to quantify productivity in the office (Pulakos, 2007; Woods, 2002). For example, Neely (1998) suggested a method of quantifying past actions that determine current performance using efficiency and effectiveness as fundamental dimensions of performance. The author described efficiency as a measure of how economically the organisation's resources are utilised when providing a given level of customer satisfaction, and effectiveness as the extent to which customer requirements are met. Oseland (1999) is of the opinion that productivity is generally expressed in terms of efficiency. As such, it can be increased by either increasing output for the same input, or achieving the same output with reduced input (Haynes, 2007). In other words, productivity can be obtained by producing the same output with fewer workers or producing more output with the same number of staff.

An interesting theory which can be viewed as a means of quantifying productivity in a work environment is that suggested by The US General Service Administration (GSA) (WBDG, 2012). It concluded that since people are the most valuable resource and greatest on-going expense of any organisation, the long-term cost benefits of a properly designed, user-friendly work environment should be factored into any initial cost considerations. WBDG (2012) suggested that one way to do such "factoring" would be to consider the total life-cycle costs of the building or property each year. It explains that an additional $\$ 2$ per square foot per year for bricks and mortar costs (e.g. for providing greater flexibility) would pay for itself if it generated a modest $1 \%$ increase in salary "productivity." As such, design strategies that increase user satisfaction and improve individual and group effectiveness should, therefore, be considered not as cost 'extras,' but as productivity investments that enhance an organisation's overall success.

Zhao et al. (2009)'s productivity model suggests that productivity varies with time from a developing stage to a mature stage to a decline stage. This notion brings to light another fact about productivity - in particular, change in productivity (increase or decrease) - that it is not constant. Irrespective of the comfort level that is provided and 
how satisfied an occupant might be with an office environment, any increase in productivity is bound not to be maintained but to decline within a particular work time.

To illustrate this theory, let's assume that the productivity of occupants in a workplace is increased (notwithstanding the individual difference between occupants i.e. all things being equal). This increase could be as a result of an intervention on the work environment that causes satisfaction, comfort or even excitement with the new working conditions (e.g. novelty effect). At the end of this time of environmental awareness and familiarisation with the environment, the excitement stops ('Mature stage') even though satisfaction and/or comfort might not have reduced. At this stage, productivity remains the same (neither increasing nor decreasing). A time comes when the environment has become too familiar and standard that there is no more excitement. Then, productivity begins to drop and decline to tend towards the initial level. In this case, the IEQ has not changed but has been kept constant as at the time of introduction. This theory could explain factors such as complacency as causes of change in productivity. A likely source is 'emotional labour' -a situation where workers are expected to manage their feelings by organisationally defined rules and guidelines (Wharton, 2009). For instance, in white collar jobs that often involve selling one's personality along with one's labour ability, these workers are likely to get tired rapidly after some time which might cause a decline in productivity. This situation is not a function of the IEQ in the office environment.

Occupant productivity is indeed a complex phenomenon to measure. However, the various definitions of productivity given by researchers above indicate that the closest attempt to capture and thus measure productivity in its totality will require both objective and subjective performance measures that consider the intricacies of not just inputs and outputs but the interactions that are evident in today's modern office. This is necessary where results of studies on IEQ and productivity are used as commercial incentives (Onyeizu, 2014). Self-evaluation does not provide an adequate platform for this.

\subsection{Diversity in Preference}

A workspace cannot be designed to be a one-time, final and permanent ergonomic support for all office tasks but rather needs to be adaptable and 'negotiable' to be supportive to users (Vischer, 2008). This is because people differ and respond differently to the same conditions (Frontczak and Wargocki, 2011). Studies that try to measure occupants' perception of their productivity under varying IEQ conditions with the aim of finding absolute correlations are often prone to the limitation that even though the physical requirements specified by research are met, not all building occupants are satisfied and motivated to perform specified tasks by the same physical conditions.

Many firms and organisations have workers from different backgrounds and cultures with different past experiences; and expectations. This diversity determines how various factors can affect productivity. It is possible that an occupant's response to any given environmental condition might be influenced by his/her perception of what an ideal environment should be from his/her experiences; which might not be the same as his/her colleagues. For instance, an occupant who has spent most of his/her lifetime in a warmer climate with less artificial lighting and continuous background noise might prefer an indoor environment closer to this situation. Also, an occupant whose experience has resulted in the preference for an individual space with minimal communication/ interference with colleagues might find an open plan workspace undesirable or detrimental to his productivity.

\subsection{Comfort/Satisfaction and productivity}

The relationship between comfort/satisfaction and productivity (Huizenga et al., 2006; Brager and Baker, 2009; Leaman and Bordass, 2001) has been an anchor in measuring the effect of IEQ on occupant productivity. Vischer (2008) noted that the link between satisfaction and productivity is the notion of comfort, specifically functional comfort which is an environmental support for users' performance of work-related tasks and activities. However, it is questionable whether comfort automatically results in productivity. It is possible that factors which amount to a comfortable environment might not be the best for a productive environment. For instance, Pepler and Warner (1968) found that young people worked best (and were thus more productive) for short periods when they were uncomfortably cold. The aim to escape the discomfort of the cold environment was in this case, a positive factor to stimulate greater productivity. Since this effect was found amongst young people (which makes up $90 \%$ of most organisations and are regarded as the healthy age group), one could draw on this and suggest that a bit of discomfort may have a positive effect on productivity. 
On the other hand, determining what could scientifically indicate a comfortable environment is also the subject of debate. While some authors stipulate a certain range of IEQ as criteria for comfort, others suggest that there are no context-free indicators for indoor climates. Roaf (2005) pointed out that the conditions which people will find comfortable are influenced by the climatic, cultural, social and economic circumstances in which they find themselves. She added that even if it is possible to suggest an appropriate indoor temperature for various types of building purposes, it depends on the social and climatic context. Monfared and Sharples (2011) observed that the expectations of occupants in buildings are inevitably based on their previous experience of conventional workplaces and lack of control over environmental conditions.

\section{Conclusion}

In this paper, we revisited the theory behind perception study and discussed the various potential issues that can affect the quality of results. The intention of this review is to highlight the insufficiency of self-evaluation in measuring occupant productivity (cognitive performance) and the influence of IEQ on it. The discussions carried out in this paper showed that self-evaluation is compromised by various issues that significantly affect the validity of their results. We also demonstrated that measuring productivity in an office environment is often limited by various issues. Thus, self-evaluation is insufficient and does not accurately measure productivity. As such, it cannot be claimed that a comfortable IEQ results in a productive occupant based on results from self-evaluation studies.

That said, we cannot make light the important of measuring how productive an occupant is and how external factors can influence this productivity to the success of an organisation. However, accurate measurement is essential that recognises occupant productivity in totality and various factors in play in an office environment. To accurately measure the effect of factors (in this case, IEQ) on productivity, the issues discussed in this paper need to be addressed. The question then is: If self-evaluation does not provide an adequate platform to test the effect of IEQ on occupant productivity, what other method is? To answer this question, more research into other methods of investigation is required. A critical review of survey instruments such as IQ test, time logs, occupants' activity records, etc. is required to ascertain their adequacy and accuracy. Also, this review has been carried out on available literature. There is need for empirical evidence to test the reliability of self -evaluation in measuring productivity and the effect of factors such as IEQ on it.

\section{References}

Abdou, O., Gamal, M. \& Abdou, A. (2006). Correlation between Indoor Environmental Quality and Productivity in Buildings. 19th International Association for people-environment studies. Alexandria, Egypt.

Annika, F., Holger W., Marcel J., \& Lukas, W., (2013) Impact of Sustainable Office Buildings on Occupant's Comfort and Productivity. Journal of Corporate Real Estate 15(1) pp 7-34.

Baird, G. (2010). Sustainable Buildings in Practice: What the Users think: Routledge Taylor \& Francis Group, 2 Park Square, Milton Park, Abingdon, Oxon OX14 4RN.

Baird, G., Leaman, A., \& Thompson, J. (2012). A comparison of the performance of sustainable buildings with conventional buildings from the point of view of the users. Architectural Science Review, 55(2), 135 144. doi:10.1080/00038628.2012.670699.

Baird, G., \& Thompson, J. (2012). Lighting conditions in sustainable buildings: results of a survey of users' perceptions. Architectural Science Review, 55(2), 102-109. doi:10.1080/00038628.2012.667941.

Brager, S. \& Baker, L. (2009). Occupant satisfaction in mixed-mode buildings. Building Research \& Information, 37(4), 369-380. doi:10.1080/09613210902899785.

Brauer, C. \& Mikkelsen, S. (2010). The influence of individual and contextual psychosocial work factors on the perception of the indoor environment at work: a multilevel analysis. International Architectural Occupation Environment Health, 83(6), 639-651. doi:10.1007/s00420-010-0511-9.

Buttonwood, (2013). Technology and our standard of living: Are we really better off than the numbers show? The Economist. Accessed 9/10/2013 from: http://www.economist.com/blogs/buttonwood/2013/08/technology-and-our-standard-living .

CABE, (2004). The impact of office design on business performance. A report for Architecture \& the Built Environment and the British Council for Offices, May 2005. Accessed 24/04/2012 from: http://webarchive.nationalarchives.gov.uk/20110118095356/http:/www.cabe.org.uk/files/impact-officedesign-full-research.pdf.

Callegaro, M. (2008). Social Desirability: Encyclopedia of Survey Reasearch Methods. SAGE.

Chau, C., Leung, T., \& Law M. (2006). Importance of Being Connected to the Outside in the Workplace. Architectural Science Review, 49(1), 91-98. doi:10.3763/asre.2006.4911. 
Drake, S., de Dear, R., Alessi, A., \& Deuble, M. (2010). Occupant comfort in naturally ventilated and mixedmode spaces within air-conditioned offices. Architectural Science Review, 53(3), 297-306.

Frontczak, M. \& Wargocki, P. (2011). Literature survey on how different factors influence human comfort in indoor environments. Building and Environment, 46(4), 922-937. doi:10.3763/asre.2010.0021.

Grady, S., Singh A., Syal, M. \& Korkmaz, S. (2010). Effects of Green Buildings on Employee Health and Productivity. American Journal of Public Health 100(9) September 2010.

Hameed, A. \& Amjad, S. (2009). Impact of Office Design on Employees' Productivity: A Case study of Banking Organizations of Abbottabad, Pakistan. Journal of Public Affairs, Administration and Management, $3(1), 1-13$.

Hauge, Å., Thomsen, J., \& Berker, T. (2011). User evaluations of energy efficient buildings: Literature review and further research. Advances in Building Energy Research, 5(1), 109-127. doi:10.1080/17512549.2011.582350.

Haynes, B. (2007). An Evaluation of Office Productivity Measurement. Journal of Corporate Real Estate, 9(3), 144-154.

Haynes, B. (2008). Office Productivity A Self Assessed Approach To Office Evaluation. Paper presented at the PRRES 14th Annual Conference. Accessed 9/10/2013 from: http://www.prres.net/papers/Haynes_Office_Productivity_A_Self_Assessed_Approach_To_Office_Eva luation.pdf.

Healey, K. \& Webster-Mannison, M. (2012). Exploring the influence of qualitative factors on the thermal comfort of office occupants. Architectural Science Review, 55(3), 169-175. doi:10.1080/00038628.2012.688014.

Hepner, C., \& Boser, R. (2006). Architects' Perceptions of LEED Indoor Environmental Quality Checklist Items on Employee Productivity. International Journal of Construction Education and Research, 2(3), 193208. doi:10.1080/15578770600907156.

Hróbjartsson, A. \& Norup, M. (2003). "The use of placebo interventions in medical practice--a national questionnaire survey of Danish clinicians". Evaluation \& the Health Professions 26 (2): 153-65. doi:10.1177/0163278703026002002. PMID 12789709.

Huizenga, C., Abbaszadeh, S., Zagreus, L., \& Arens, E. (2006). Air Quality and Thermal Comfort in Office Buildings: Results of a Large Indoor Environmental Quality Survey. Proceedings, Healthy Buildings 2006, Vol. III, 393-397, Lisbon, Portugal, June.

Kaarlela-Tuomaala, A., Helenius, R., Keskinen, E., \& Hongisto, V. (2009). Effects of acoustic environment on work in private office rooms and open-plan offices - longitudinal study during relocation. [Comparative Study Research Support, Non-U.S. Gov't]. Ergonomics, 52(11), 1423-1444. doi:10.1080/00140130903154579.

Kamaruzzaman S., \& Sabrani, N., (2011) The Effect of Indoor Air Quality (IAQ) towards Occupants' Psychological Performance in Office Buildings. Journal Design + Built (4). Pp 49 -61.

Kampschroer, K. \& Heerwagen, J. H. (2005). The strategic workplace: development and evaluation. Building Research \& Information, 33(4), 326-337. doi:10.1080/09613210500161976.

Kekäläinen P., Niemelä R., Tuomainen M., Kemppilä S., Palonen J., Riuttala H. \& Reijula, K. (2010). Effect of reduced summer indoor temperature on symptoms, perceived work environment and productivity in office work. Intelligent Buildings International, 2(4), 251-266. doi:10.3763/inbi.2010.0051.

Klepeis, N., Nelson, W., Ott, W., Robinson, J., Tsnag A., Switzer, P., Behar, J., Hern, S. \& Engelmann, W., (2001). The National Human Activity Pattern Survey (NHAPS): A resource for assessing exposure to environmental pollutants, Journal of Exposure Analysis and Environmental Epidemiology, 11, 231 -252

Kim, S. \& Kim, J. (2007). Influence of light fluctuation on occupant visual perception. Building and Environment, 42(8), 2888-2899. doi:10.1016/j.buildenv.2006.10.033

Kumar, S. \& Fisk, W. (2002) The Role of Emerging Energy-Efficient Technology in Promoting Workplace Productivity and Health1: Final Report. Lawrence Berkeley National Laboratory.. Accessed 11/4/2013 from: http://www.escholarship.org/uc/item/0sw558qr

Lan, L., \& Lian, Z. (2009). Use of neurobehavioral tests to evaluate the effects of indoor environment quality on productivity. Building and Environment, 44(11), 2208-2217. doi:10.1016/j.buildenv.2009.02.001.

Leaman, A. (2012). Usable Buildings. Accessed 4/04/2014 from: http://www.usablebuildings.co.uk

Leaman, A. \& Bordass, B. (2007) Are building users more tolerant of Green buildings? Building Research \& Information, 35:6, 662-673, DOI: 10.1080/09613210701529518.

Leaman, A., \& Bordass, B. (2001). Assessing building performance in use 4: the Probe occupant surveys and their implications. Building Research \& Information, 29(2), 129-143. doi:10.1080/09613210010008045.

Leblebici, D. (2012). Impact of Workplace Quality on Employees' Productivity: Case Study of a Bank In Turkey. Journal of Business, Economics \& Finance, 1(1), 38 - 49.

Lee, S., \& Brand, J. (2010). Can personal control over the physical environment ease distractions in office workplaces? Ergonomics, 53(3), 324-335. doi:10.1080/00140130903389019.

Lee, S. \& Kim, S. (2008) Indoor Environment Quality in LEED_Certified Buildings in the U.S. Journal of Asain Architecture and Building Engineering (JAABE) 7(2) pg 293-300 
Lee, S. (2000). Understanding productivity improvement in a turbulent environment: A symposium introduction. Public Productivity \& Management Review, 23, 423-427.

Lenoir, A., Baird, G. \& Garde, F. (2012). Post-occupancy evaluation and experimental feedback of a net zeroenergy building in a tropical climate. Architectural Science Review, 55(3), 156-168. doi:10.1080/00038628.2012.702449.

Levitt, S. \& List, J. (2007). What Do Laboratory Experiments Measuring Social Preferences Reveal about the Real World? The Journal of Economic Perspectives, 21(2), 153-174. doi:10.2307/30033722.

Levitt, S. \& List, J. (2011). Was There Really a Hawthorne Effect at the Hawthorne Plant? An Analysis of the Original Illumination Experiments. American Economic Journal: Applied Economics, 3(1), 224-238. doi:10.1257/app.3.1.224.

Liu, K., Chiang, C. \& Lin, Y. (2010). Influences of visual fatigue on the productivity of subjects using visual display terminals in a light-emitting diode lighting environment. Architectural Science Review, 53(4), 384-395.

Mak, C. \& Lui, Y. (2012). The effect of sound on office productivity. Building Services Engineering Research and Technology, 33(3), 339-345. doi:10.1177/0143624411412253.

McCunn, L. \& Gifford, R. (2012). Do Green offices affect employee engagement and environmental attitudes? Architectural Science Review, 55(2), 128-134. doi:10.1080/00038628.2012.667939.

McCarney, R., Warner, J., Iliffe, S., van Haselen, R., Griffin, M. \& Fisher, P. (2007). "The Hawthorne Effect: a randomised, controlled trial". BMC Med Res Methodol 7: 30. doi:10.1186/1471-2288-7-30. PMC 1936999. PMID 17608932.

Meijer, E., Frings-Dresen, M. \& Sluiter, J. (2009). Effects of office innovation on office workers' health and performance. Ergonomics, 52(9), 1027-1038. doi:10.1080/00140130902842752.

Monfared, I. \& Sharples, S. (2011). Occupants' perceptions and expectations of a Green office building: a longitudinal case study. Architectural Science Review, 54(4), 344-355. doi:10.1080/00038628.2011.613636\#2011.

Mulville, M., Callaghan, N. and Isaac, D. (2016) 'The impact of the ambient environment and building configuration on occupant productivity in open-plan commercial offices', Journal of Corporate Real Estate, 18(3), pp. 180-193. doi: 10.1108/jcre-11-2015-0038.

Neely, A. (1998). Measuring Business Performance, Economist Books, London.

Newsham, G., Brand, J., Donnelly, C., Veitch, J., Aries, M., \& Charles, K., (2009). Linking indoor environment conditions to job satisfaction: a field study, Building Research \& Information, 37:2, 129-147.

Onyeizu E \& Byrd H. (2014). Are IEQ factors more important to productivity than other factors in the workplace? 50th ASC Annual International Conference, March 26-28, 2014 Virginia, USA.

Onyeizu, E. (2014) Can Architecture Increase Productivity? A Case of Green Buildings. PhD Thesis, The University of Auckland.

Oseland, N. (1999). Environmental Factors Affecting Office Worker Performance: A Review of Evidence, Technical Memoranda TM24: CIBSE, London.

Paevere, P., \& Brown, S. (2008). Indoor Environment Quality and Occupant Productivity in the CH2 Building in SB08 : Proceedings of the 2008 International Scientific Committee World Sustainable Building Conference, [ASN Events], [Balnarring, Vic.], pp. 222-229.

Pepler, R., \& Warner, R. (1968). Temperature and Learning: an experimental study. ASHRAE Transactions, 74(2), 11-19.

Prakash, P. (2005). Effect of indoor environmental quality on occupant's perception of performance: A comparative study. Master of interior design Thesis, University of Florida, USA. 2005.

Pulakos, E. (2007) Performance measurement. Applied measurement: Industrial psychology in human resources management. Book Chapter by Whetzel D. \& Wheaton G. Mahwah, N.J. : Lawrence Erlbaum Associates, 2007 pg 293.

Roaf S. (2005). Closing the loop: Benchmarks for sustainable buildings. RIBA Publications, London.

Roethlisberger, F. \& Dickson, W. (1939). Management and the Worker. Cambridge, MA.: Havard Univeristy Press.

Rosenthal, R. (2004). Experimenter Expectancy Effect in Encyclopedia of social science research methods. Editors: Lewis-Beck M., Bryman A and Liao T. SAGE Publications Inc. 357-358.

Roulet, C., Johner, N., Foradini, F., Bluyssen, P., Cox, C., De Oliveira Fernandes, E., \& Aizlewood, C. (2006). Perceived health and comfort in relation to energy use and building characteristics. Building Research \& Information, 34(5), 467-474. doi:10.1080/09613210600822279.

Sensharma N., Woods J., \& Goodwin A. (1998). Relationships between the indoor environment and productivity: A literature review. ASHRAE Transactions. 104 (part 1A), pp 686-701.

Smith, M., \& Bayehi, A. (2003). Do ergonomics improvements increase computer workers' productivity?: an intervention study in a call centre. [Comparative Study Research Support, U.S. Gov't, P.H.S.]. Ergonomics, 46(1-3), 3-18. doi:10.1080/00140130303522. 
Tanabe, S., Iwahashi, Y., Tsushima, S., \& Nishihara, N. (2013). Thermal comfort and productivity in offices under mandatory electricity savings after the Great East Japan earthquake. Architectural Science Review, 1-10. doi:10.1080/00038628.2012.744296.

Thomas, L. (2010). Evaluating design strategies, performance and occupant satisfaction: a low carbon office refurbishment. Building Research \& Information, 38(6), 610-624. doi:10.1080/09613218.2010.501654.

Vischer, J. (2008). Towards an environmental Psychology of Workspace: How People are affected by Environments for Work. Architectural Science Review, 51(2), 97-108.

Wharton, A. (2009). The Sociology of Emotional Labor. Annual Review of Sociology 34: 147-65.

Woods, J. (2002). Research Protocols for Evaluating the Relationship between the Indoor Environment and Productivity: Final Report ASHRAE Research Project 700-RP. Atlanta, George 30329.

World Building Design Guide (WBDG) (2012). Productive. Productive Committee Accessed 9/10/2013 from: http://www.wbdg.org/design/productive.php .

Yang, H., Chen, X., \& Zelinsky, G. (2009). A new look at novelty effects: Guiding search away from old distractors. Attention, Perception, \& Psychophysics 2009, 71 (3), 554-564 doi:10.3758/APP.71.3.554.

Zagreus L., Huizenga C., Arens E., and Lehrer D., (2004). Listening to the Occupants: a Web-based indoor environmental quality survey. Indoor Air 14(8) 65-74.

Zhang, H., Arens, E., \& Pasut, W. (2011). Air temperature thresholds for indoor comfort and perceived air quality. Building Research \& Information, 39(2), 134-144. doi:10.1080/09613218.2011.552703.

Zhao, J., Zhu, N., \& Lu, S. (2009). Productivity model in hot and humid environment based on heat tolerance time analysis. Building and Environment, 44(11), 2202-2207. doi:10.1016/j.buildenv.2009.01. 
Table 1: Basic information on self-evaluation studies on the relationship between IEQ and Productivity. Source: Author

\begin{tabular}{|c|c|c|c|c|c|c|c|}
\hline No & Year & Author(s) & Sources & IEQ factor tested & Sample population & $\begin{array}{l}\text { Instrument(s) } \\
\text { applied }\end{array}$ & Summary of findings \\
\hline 1 & 2001 & $\begin{array}{l}\text { Leaman \& } \\
\text { Bordass }\end{array}$ & $\begin{array}{l}\text { Building Research \& } \\
\text { Information }\end{array}$ & $\begin{array}{l}\text { Temperature, } \\
\text { lighting, noise, air } \\
\text { quality }\end{array}$ & $\begin{array}{l}\text { Workers in UK office } \\
\text { buildings }\end{array}$ & $\begin{array}{l}\text { BUS } \\
\text { questionnaire }\end{array}$ & $\begin{array}{l}\text { Noise level is most strongly associated with perceived productivity even } \\
\text { though the relationship is weak. }\end{array}$ \\
\hline 2 & 2005 & Prakash & $\begin{array}{l}\text { Masters project } \\
\text { Thesis - University of } \\
\text { Florida }\end{array}$ & $\begin{array}{l}\text { Temperature, } \\
\text { illuminance and } \\
\text { noise }\end{array}$ & $\begin{array}{l}80 \text { occupants in a LEED } \\
\text { and non-LEED certified } \\
\text { buildings. }\end{array}$ & $\begin{array}{l}\mathrm{CBE} \\
\text { questionnaire }\end{array}$ & $\begin{array}{l}\text { Occupants in the LEED certified building felt daylighting and thermal } \\
\text { comfort had positive effect on their productivity. Occupants in the Non- } \\
\text { LEED certified building felt that the good overall ambient of the building } \\
\text { improved their productivity. }\end{array}$ \\
\hline 3 & 2006 & $\begin{array}{l}\text { Roulet et } \\
\text { al. }\end{array}$ & $\begin{array}{l}\text { Building Research \& } \\
\text { Information }\end{array}$ & $\begin{array}{l}\text { Temperature, Noise, } \\
\text { Air quality, } \\
\text { Lighting. }\end{array}$ & $\begin{array}{l}\text { Occupants in } 64 \text { office } \\
\text { buildings }\end{array}$ & Questionnaire & Perceived productivity correlated with temperature. \\
\hline 4 & 2007 & $\begin{array}{l}\text { Kim and } \\
\text { Kim }\end{array}$ & $\begin{array}{l}\text { Building and } \\
\text { Environment }\end{array}$ & $\begin{array}{l}\text { Various } \quad \text { IEQ } \\
\text { factors }\end{array}$ & $\begin{array}{l}\text { POE database of } 42,764 \\
\text { respondents in } 303 \\
\text { office buildings. }\end{array}$ & $\begin{array}{l}\text { CBE } \\
\text { questionnaire }\end{array}$ & $\begin{array}{l}\text { Noise level and visual privacy affected workspace satisfaction which is } \\
\text { closely related to perceived productivity }\end{array}$ \\
\hline 5 & 2008 & Haynes & $\begin{array}{l}\text { Journal of Facilities } \\
\text { Management }\end{array}$ & $\begin{array}{l}\text { Temperature, } \\
\text { lighting, noise, } \\
\text { ventilation, air } \\
\text { quality }\end{array}$ & $\begin{array}{l}996 \text { workers in office } \\
\text { buildings. }\end{array}$ & Questionnaire & $\begin{array}{l}\text { Physical components of comfort were not enhancing perceived } \\
\text { productivity. Rather, interaction and distraction had an effect on } \\
\text { perceived productivity. }\end{array}$ \\
\hline 6 & 2008 & $\begin{array}{l}\text { Paevere \& } \\
\text { Brown }\end{array}$ & $\begin{array}{l}\text { Proceedings of the } \\
2008 \text { International } \\
\text { Scientific Committee } \\
\text { World Sustainable } \\
\text { Building Conference }\end{array}$ & $\begin{array}{l}\text { Temperature, air } \\
\text { quality, noise and } \\
\text { lighting }\end{array}$ & $\begin{array}{l}\text { Occupants of Council } \\
\text { House } 2 \text { in Melbourne }\end{array}$ & $\begin{array}{l}\text { BUS } \\
\text { questionnaire } \\
\text { and focus } \\
\text { group } \\
\text { interviews. }\end{array}$ & $\begin{array}{l}4.9 \% \text { increase in staff productivity due to improved IEQ. Focus group } \\
\text { interviews highlighted the difficulty of distinguishing between building- } \\
\text { related impacts on productivity from other factors such as workplace } \\
\text { restructuring. }\end{array}$ \\
\hline 7 & 2008 & $\begin{array}{l}\text { Lee and } \\
\text { Kim }\end{array}$ & $\begin{array}{l}\text { Journal of Asian } \\
\text { Architecture and } \\
\text { Building Engineering }\end{array}$ & $\begin{array}{l}\text { Thermal Comfort, } \\
\text { Indoor Air Quality, } \\
\text { Lighting, Acoustics }\end{array}$ & $\begin{array}{l}\text { CBE database of } 15 \\
\text { LEED-certified } \\
\text { buildings and } 200 \text { non- } \\
\text { LEED-certified } \\
\text { buildings }\end{array}$ & $\begin{array}{l}\text { CBE } \\
\text { questionnaire }\end{array}$ & $\begin{array}{l}\text { LEED-certified buildings had higher occupant performance in thermal } \\
\text { comfort and IAQ. Non-LEED-certified buildings showed higher } \\
\text { occupant performance in lighting and acoustic quality. }\end{array}$ \\
\hline 8 & 2009 & $\begin{array}{l}\text { Kaarlela- } \\
\text { Tuomaala } \\
\text { et al. }\end{array}$ & Ergonomics & Noise & $\begin{array}{l}31 \text { workers who moved } \\
\text { from a private office } \\
\text { room to open-plan } \\
\text { office }\end{array}$ & Questionnaire & $\begin{array}{l}\text { Significant correlation between noise levels and productivity of workers. } \\
\text { The authors concluded that an open plan office is not recommended for } \\
\text { professional workers. }\end{array}$ \\
\hline 9 & 2009 & $\begin{array}{l}\text { Newsham } \\
\text { et al. }\end{array}$ & $\begin{array}{l}\text { Building Research \& } \\
\text { Information }\end{array}$ & $\begin{array}{l}\text { Lighting, noise, } \\
\text { ventilation }\end{array}$ & 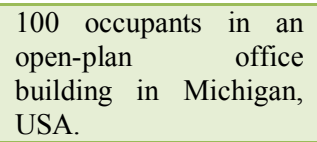 & Questionnaire & $\begin{array}{l}\text { Significant link between overall environmental satisfaction and job } \\
\text { satisfaction. However, no correlation was found for lighting, acoustics, } \\
\text { ventilation and job stress. }\end{array}$ \\
\hline 10 & 2009 & $\begin{array}{l}\text { Hameed } \\
\& \text { Amjad }\end{array}$ & $\begin{array}{l}\text { Journal of Public } \\
\text { Affairs, } \\
\text { Administration and }\end{array}$ & $\begin{array}{l}\text { Noise, lighting and } \\
\text { temperature }\end{array}$ & $\begin{array}{l}105 \text { employees in } 13 \\
\text { banks in Pakistan }\end{array}$ & Questionnaire & Lighting most affected the productivity of workers \\
\hline
\end{tabular}




\begin{tabular}{|c|c|c|c|c|c|c|c|}
\hline & & & Management & & & & \\
\hline 11 & 2010 & Baird & $\begin{array}{l}\text { Routledge Taylor \& } \\
\text { Francis Group, }\end{array}$ & $\begin{array}{l}\text { Temperature, } \\
\text { lighting, noise, air } \\
\text { quality }\end{array}$ & $\begin{array}{l}\text { Occupants of } 30 \text { Green- } \\
\text { certified buildings } \\
\text { around the world }\end{array}$ & $\begin{array}{l}\text { BUS } \\
\text { questionnaire } \\
\text { and interviews }\end{array}$ & Significant increase in productivity associated with Green IEQ. \\
\hline 12 & 2010 & $\begin{array}{l}\text { Grady et } \\
\text { al. }\end{array}$ & $\begin{array}{l}\text { American Journal of } \\
\text { Public Health }\end{array}$ & $\begin{array}{l}\text { Air quality, } \\
\text { temperature, } \\
\text { humidity, } \\
\text { ventilation, lighting, } \\
\text { noise }\end{array}$ & $\begin{array}{l}175 \text { employees of a } \\
\text { LEED-certified office } \\
\text { building. }\end{array}$ & Questionnaire & Reductions in absenteeism and work hours as a result of improved IEQ \\
\hline 13 & 2010 & Thomas & $\begin{array}{l}\text { Building Research \& } \\
\text { Information }\end{array}$ & $\begin{array}{l}\text { Air quality, } \\
\text { temperature, } \\
\text { lighting and noise }\end{array}$ & $\begin{array}{lr}\begin{array}{l}\text { Occupants of a low } \\
\text { carbon } \\
\text { refurbishment }\end{array} \\
\text { office } \\
\text { Sydney, Australia }\end{array}$ & $\begin{array}{l}\text { BUS } \\
\text { questionnaire }\end{array}$ & $\begin{array}{l}7.21 \% \text { increase in productivity as a result of environmental conditions in } \\
\text { the building. }\end{array}$ \\
\hline 14 & 2010 & $\begin{array}{l}\text { Kekalaine } \\
\mathrm{n} \text { et al. }\end{array}$ & $\begin{array}{l}\text { Intelligent Buildings } \\
\text { International }\end{array}$ & $\begin{array}{l}\text { Summer indoor } \\
\text { temperature }\end{array}$ & $\begin{array}{l}\text { Occupants of an office } \\
\text { building in Helsinki, } \\
\text { Finland }\end{array}$ & Questionnaire & $\begin{array}{l}\text { Work efficiency increased after renovation of an HAVC system in the } \\
\text { office. } 4.4 \% \text { improvement was reported. }\end{array}$ \\
\hline 15 & 2010 & $\begin{array}{l}\text { Lee \& } \\
\text { Brand }\end{array}$ & Ergonomics & $\begin{array}{lr}\text { Personal r } & \text { control } \\
\text { over r physical } \\
\text { environment }\end{array}$ & $\begin{array}{l}384 \text { employees in } \\
\text { corporate office of } 3 \\
\text { manufacturing } \\
\text { companies in Michigan, } \\
\text { USA }\end{array}$ & Questionnaire & $\begin{array}{l}\text { The perception of control over aspects of the physical environment } \\
\text { mediated the relationship between perceived job performances. }\end{array}$ \\
\hline 16 & 2010 & $\begin{array}{l}\text { Drake et } \\
\text { al. }\end{array}$ & $\begin{array}{l}\text { Architectural Science } \\
\text { Review }\end{array}$ & Temperature & $\begin{array}{l}\text { Staff in air-conditioned } \\
\text { and naturally ventilated } \\
\text { office buildings }\end{array}$ & Questionnaire & $\begin{array}{l}\text { Productivity of occupants in Air conditioned building decreased by - } \\
0.5 \% \text { while occupants in the naturally ventilated building perceived no } \\
\text { change in their productivity. }\end{array}$ \\
\hline 17 & 2010 & $\begin{array}{l}\text { Brauer \& } \\
\text { Mikkelsen }\end{array}$ & $\begin{array}{l}\text { International } \\
\text { Architectural } \\
\text { Occupation } \\
\text { Environment Health }\end{array}$ & $\begin{array}{l}\text { Temperature, noise, } \\
\text { lighting, air quality }\end{array}$ & $\begin{array}{l}3,281 \text { employees in } 39 \\
\text { workplaces. }\end{array}$ & Questionnaire & $\begin{array}{l}\text { Importance of psychosocial work environment at an individual level on } \\
\text { performance. }\end{array}$ \\
\hline 18 & 2011 & $\begin{array}{l}\text { Zhang et } \\
\text { al. }\end{array}$ & $\begin{array}{l}\text { Building Research \& } \\
\text { Information }\end{array}$ & $\begin{array}{l}\text { Temperature and } \\
\text { Air-quality }\end{array}$ & $\begin{array}{l}72 \quad \text { buildings in } \\
\text { ASHRAE database }\end{array}$ & Questionnaire & No obvious best temperature for productivity \\
\hline 19 & 2011 & $\begin{array}{l}\text { Monfared } \\
\& \\
\text { Sharples }\end{array}$ & $\begin{array}{l}\text { Architectural Science } \\
\text { Review }\end{array}$ & All IEQ factors & $\begin{array}{l}\text { Occupants in two Green } \\
\text { UK government office } \\
\text { buildings. }\end{array}$ & Questionnaire & $\begin{array}{l}\text { Green identity of the buildings had a greater influence on the occupants' } \\
\text { perception than IEQ in the buildings. }\end{array}$ \\
\hline 20 & 2011 & $\begin{array}{l}\text { Kamaruzz } \\
\text { aman and } \\
\text { Sabrani }\end{array}$ & $\begin{array}{l}\text { Journal Design }+ \\
\text { Built }\end{array}$ & Indoor Air Quality & $\begin{array}{l}\text { Occupants of } 4 \text { office } \\
\text { buildings }\end{array}$ & Questionnaire & $\begin{array}{l}\text { The increase in productivity as a result of the Indoor Air Quality was } \\
\text { slightly low. }\end{array}$ \\
\hline 21 & 2012 & $\begin{array}{l}\text { Baird \& } \\
\text { Thompson }\end{array}$ & $\begin{array}{l}\text { Architectural Science } \\
\text { Review }\end{array}$ & Lighting & $\begin{array}{l}2540 \text { occupants of } 36 \\
\text { commercial and } \\
\text { institutional buildings. }\end{array}$ & $\begin{array}{l}\text { BUS } \\
\text { questionnaire }\end{array}$ & A correlation wasfound between lighting and productivity of occupants. \\
\hline 22 & 2012 & $\begin{array}{l}\text { Baird et } \\
\text { al. }\end{array}$ & $\begin{array}{l}\text { Architectural Science } \\
\text { Review }\end{array}$ & $\begin{array}{l}\text { Temperature, } \\
\text { lighting, noise and } \\
\text { air quality }\end{array}$ & $\begin{array}{l}\text { Occupants of } 31 \text { Green- } \\
\text { certified buildings and } \\
109 \quad \text { conventional } \\
\text { buildings }\end{array}$ & $\begin{array}{l}\text { BUS } \\
\text { questionnaire }\end{array}$ & $\begin{array}{l}\text { Occupants of green certified buildings reported higher productivity than } \\
\text { those in conventional buildings as a result of the IEQ. }\end{array}$ \\
\hline
\end{tabular}




\begin{tabular}{|c|c|c|c|c|c|}
\hline 23 & 2012 & $\begin{array}{l}\text { Lenoir et } \\
\text { al. }\end{array}$ & $\begin{array}{l}\text { Architectural Science } \\
\text { Review }\end{array}$ & $\begin{array}{l}\text { Temperature, } \\
\text { lighting, noise and } \\
\text { air quality }\end{array}$ & $\begin{array}{l}\text { Staff and students in the } \\
\text { ENERPOS building in } \\
\text { La Reunion }\end{array}$ \\
\hline 24 & 2012 & $\begin{array}{l}\text { Mak \& } \\
\text { Lui }\end{array}$ & $\begin{array}{l}\text { Building Services } \\
\text { Engineering Research } \\
\text { and Technology }\end{array}$ & Sound & $\begin{array}{l}259 \text { office workers in } \\
38 \text { air-conditioned } \\
\text { offices in Hong Kong. }\end{array}$ \\
\hline 25 & 2012 & $\begin{array}{l}\text { McCunn } \\
\text { \& Gifford }\end{array}$ & $\begin{array}{l}\text { Architectural Science } \\
\text { Review }\end{array}$ & $\begin{array}{l}\text { Green } \\
\text { attributes }\end{array}$ & $\begin{array}{l}77 \text { employees in } 15 \\
\text { public and private } \\
\text { sector office buildings. }\end{array}$ \\
\hline 26 & 2012 & $\begin{array}{l}\text { Healey \& } \\
\text { Webster- } \\
\text { Mannison }\end{array}$ & $\begin{array}{l}\text { Architectural Science } \\
\text { Review }\end{array}$ & Temperature & $\begin{array}{l}9 \text { office workers in an } \\
\text { architectural design } \\
\text { practice - pilot study }\end{array}$ \\
\hline 27 & 2012 & Leblebici & $\begin{array}{l}\text { Journal of Business, } \\
\text { Economics \& Finance }\end{array}$ & $\begin{array}{l}\text { Ventilation, } \\
\text { Lighting, overall } \\
\text { comfort }\end{array}$ & $\begin{array}{l}50 \text { employees in an } \\
\text { office building. }\end{array}$ \\
\hline 28 & 2013 & $\begin{array}{l}\text { Tanabe et } \\
\text { al. }\end{array}$ & $\begin{array}{l}\text { Architectural Science } \\
\text { Review }\end{array}$ & $\begin{array}{l}\text { Temperature, } \\
\text { lighting, ventilation }\end{array}$ & $\begin{array}{l}\text { Occupants of five office } \\
\text { buildings in Tokyo }\end{array}$ \\
\hline 29 & 2013 & $\begin{array}{l}\text { Annika et } \\
\text { al., }\end{array}$ & $\begin{array}{l}\text { Journal of Corporate } \\
\text { Real Estate }\end{array}$ & $\begin{array}{l}\text { Lighting, } \\
\text { Quality, } \\
\text { Climate }\end{array}$ & $\begin{array}{l}1,500 \text { employees in } 18 \\
\text { office buildings }\end{array}$ \\
\hline 30 & 2016 & $\begin{array}{l}\text { Mulville } \\
\text { et al., }\end{array}$ & $\begin{array}{l}\text { Journal of Corporate } \\
\text { Real Estate }\end{array}$ & $\begin{array}{l}\text { Thermal Comfort, } \\
\text { Indoor Air Quality, } \\
\text { Lighting, Acoustics, }\end{array}$ & $\begin{array}{l}\text { Occupants in } 30 \\
\text { workstations of an } \\
\text { open-plan office. }\end{array}$ \\
\hline
\end{tabular}

\section{BUS} and interview

Questionnaire

Questionnaire

Semi-

structured

interview

Questionnaire

CBE

questionnaire

Questionnaire and interview

Questionnaire open-plan office.
Students reported an average of $11.25 \%$ increase in productivity while the reported an average of $17.5 \%$ as result of the better in the mixed-mode air conditioned building.

Significant correlation between noise, temperature and productivity.

No positive correlation was found between Green design attributes and Occupant productivity.

Highlighted the importance of cultural and contextual factors that influence comfort-related adaptation.

Environmental factors were perceived to be important to workers productivity

Productivity decreased by $6.6 \%$ when electricity saving measure was introduced - controlled relative humidity within a narrow range $(46 \%$ \& $60 \%$ ). The authors noted that loss of productivity could not purely be the result of environmental conditions.

Correlation between IEQ and Productivity was not statistically significant.

Noise levels were founds to be of particular importance to comfort, health, wellbeing and by extension productivity. It was also found that occupant behaviour had a significant influence on comfort and wellbeing

Table 2: Potential biases and associated reviewed studies

\begin{tabular}{|l|l|}
\hline Potential bias & No. of associated reviewed studies \\
\hline Hawthorne effect & All studies $(1-30)$ \\
\hline Placebo effect & Study 19,26 \\
\hline Experimenter expectancy effect & Study $1,6,11,13,21,22,23$ \\
\hline Social desirability & Studies $6,8,9,10,11,12,13,21,22,23,30$ \\
\hline Novelty effect & Study 8,13 \\
\hline Perceived productivity & All studies \\
\hline
\end{tabular}




\section{$\%$ of correlation with productivity}

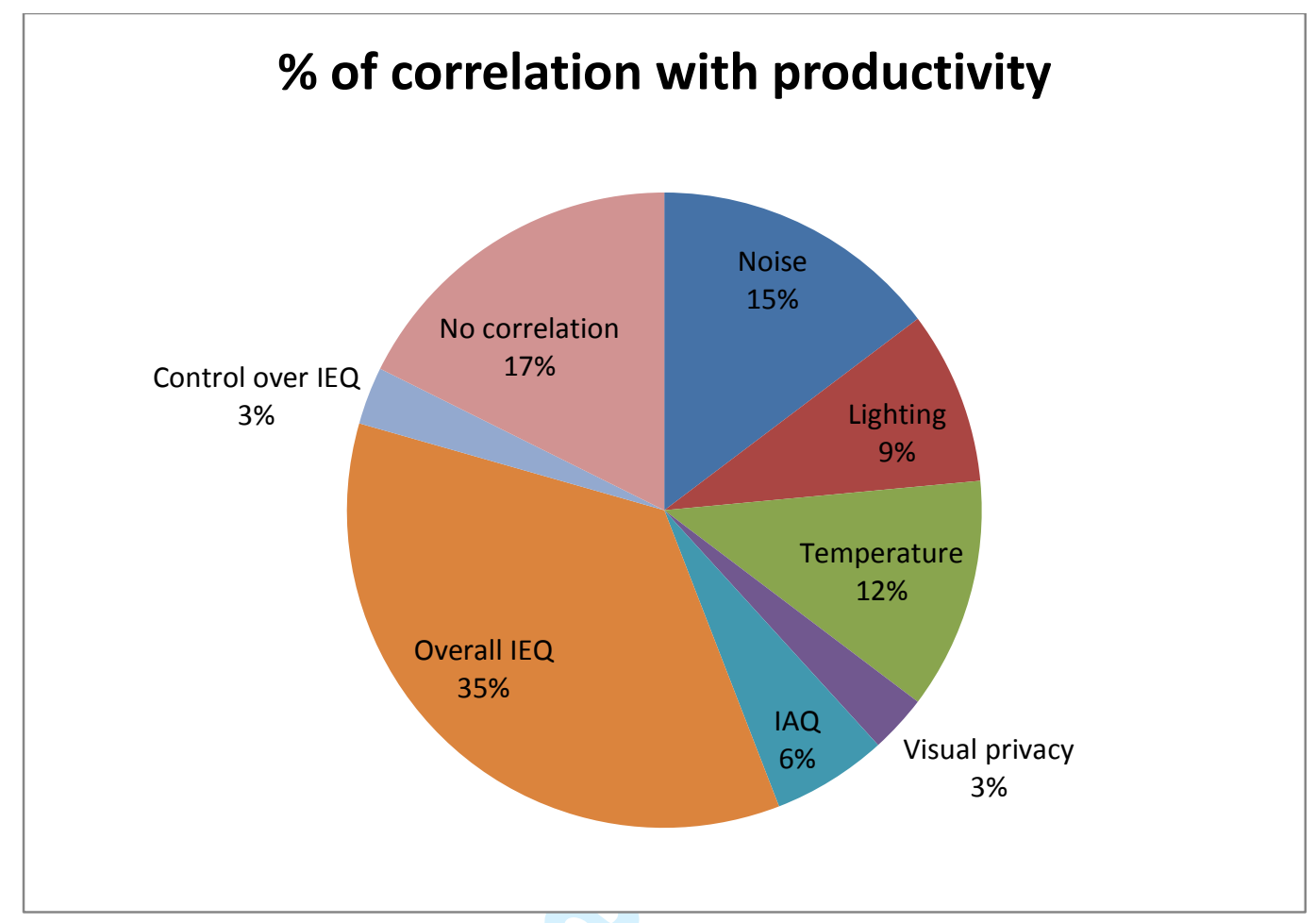

Figure 1: summary of IEQ correlation with Productivity from reviewed studies 